\title{
Using inulin based of emulsion gels as fat substitute in salt reduced Bologna sausage
}

Running title: Emulsion gels as fat substitute in salt reduced Bologna sausage

\author{
Camila de Souza Paglarinia1; Vitor Andre Silva Vidal ${ }^{a}$; Wanessa Ribeiro ${ }^{\mathrm{a}}$; Ana Paula Badan \\ Ribeiro ${ }^{\mathrm{a}}$; Oigres Daniel Bernardinellib; Ana M Herrero ${ }^{\mathrm{c}}$; Claudia Ruiz-Capillas ${ }^{\mathrm{c}}$; Edvaldo \\ Sabadinib; Marise Aparecida Rodrigues Pollonio ${ }^{\mathrm{a}}$
}

${ }^{a}$ Department of Food Technology, School of Food Engineering, University of Campinas, 13083862, Campinas, Brazil.

${ }^{b}$ Institute of Chemistry, University of Campinas, 13083-862, Campinas, Brazil.

'Institute of Food Science, Technology and Nutrition (ICTAN-CSIC), José Antonio Novais, 10, 28040 Madrid, Spain.

\section{Abstract}

BACKGROUND: A high-fiber emulsion gel (EG) containing inulin, soy protein isolate, and soybean oil was applied as animal fat replacer in reduced salt and fat Bologna sausage containing mechanically deboned chicken meat (MDCM), pork meat, and pork back fat. Technological and microbiological properties were evaluated for 60 days at 4 ${ }^{\circ} \mathrm{C}$.

RESULTS: A reduction of $11-34 \%$ and $35-45 \%$ of fat and sodium were obtained in reformulated products, respectively. An increase in fiber content and polyunsaturated fatty acid was noticed in the formulations with EG. The addition of EG in Bologna increased $L^{*}$ values and reduced $a^{*}$ values comparing to control treatment. Microstructural properties of sausages exhibited a denser network with the presence of EG. A softer, more elastic, cohesive and resilient samples with a higher intensity of lipid oxidation $(p<0.05)$ were observed in EG added sausages. The NMR data shows that the presence of EG recovers the matrix that has been weakened due to reduction of fat

\footnotetext{
${ }^{1}$ Corresponding Author. Tel.: +55 1935214002

E-mail address: camilaspaglarini@gmail.com
}

This article has been accepted for publication and undergone full peer review but has not been through the copyediting, typesetting, pagination and proofreading process which may lead to differences between this version and the Version of Record. Please cite this article as doi: 10.1002/jsfa.10659 
and salt. Sensory evaluation showed that the incorporation of the emulsion gels resulted in acceptable scores.

CONCLUSION: These results suggest that inulin based emulsion gel is a potential fat substitute for developing healthier meat products, with better fatty acids composition and stable to chilled storage.

Keywords: dietary fiber; gelled emulsion; low-salt sausage; mechanically deboned chicken meat

\section{INTRODUCTION}

Processed meat is recognized for its nutrients content such essential amino acids, minerals (iron, zinc, selenium, etc.), vitamins (mainly B group), glutathione, ubiquinone which are important for growth and development. However, it also has the negative contribution to fat (mainly saturated fatty acid (SFA), cholesterol) and sodium daily intakes. ${ }^{1} \mathrm{~A}$ recommendation to reduce the consumption of total fat (max. $30-35 \%$ of the total caloric value) and SFA (less than 10\%) and also to increase the intakes of polyunsaturated fatty acids is suggested by health organization. ${ }^{2}$ A sodium intake of less than $<5 \mathrm{~g}$ salt/day $\left(2 \mathrm{~g}\right.$ sodium/day) is also suggested. ${ }^{3}$

Emulsion gels (EGs) are structured oils and its may be suitable to improve the quality of fat in meat products. EG are generally formed by edible oils (from vegetable, marine, and others sources) in the dispersed phase, water in continuous phase, and structuring agents (proteins, fibers, etc) as emulsifiers, stabilizers and/or functional ingredients and have a solid-like lipid structure. ${ }^{4}$ The effect of adding EG in meat products such as 
burgers, ${ }^{5,6}$ meat batters, ${ }^{7}$ and dry-fermented sausage ${ }^{8}$ have been reported. The main results derived from using structured healthier oil as animal fat replacer in meat products describe a better nutritional profile by reducing total and saturated fat contents and increasing polyunsaturated fatty acids. In some cases, the formulation of EG contains functional ingredients improving others nutritional properties such as adding fibers keeping the sensorial acceptance on these reformulated products. ${ }^{8,9}$

Vegetable proteins are recognized as a ingredients with great potential to increase functional properties of reformulated meat products. In particular, soy protein isolate (SPI) is an excellent emulsifier and gelling agent ${ }^{10}$ usually added in meat products formulations to improve technological properties. ${ }^{11}$ Besides that, SPI presents good nutritional properties and is widely produced in the world ${ }^{12}$ which allow this ingredient to have a low cost.

To perform the dispersed phase of the emulsion, a great alternative economically and nutritionally is soybean oil, due to its high production, availability and low value. Moreover, its fat content consists of $15-33 \%$ oleic acid (C18:1n-9), 43-56\% linoleic acid (C18:2n-6), and 5-11\% $\alpha$-linolenic acid (C18:3n-3). ${ }^{13}$

Considering the possibility of adding a functional ingredient as part of the emulsion gel composition, inulin has been widely used in food and is commonly labeled as dietary fiber ${ }^{14,15}$ Gels formed by inulin presents small crystals of approximately $100 \mathrm{~nm}$ in diameter that form clusters larger than 1-5 $\mu \mathrm{m}$, which retain a large amount of water in 
the network, and its network properties may mimic fat crystals, which makes it a potential component to substitute fat in meat emulsion. ${ }^{16,17}$

Our previous studies have reported the optimization of an emulsion gel to be used as a fat replacer in meat emulsion ${ }^{18}$ and its application in frankfurter ${ }^{19}$ and Bologna sausage

9. The results have shown us that it is a promising fat substitute by obtaining products with healthier nutritional profile and technological properties similar to a control product. However, the study of the stability in low cost and reduced-salt meat emulsions containing EG during shelf life is scarse in the literature suggesting that more thorough research needs to be conducted. Then, the goal of this study was to evaluate the effect of emulsion gel with soybean oil, SPI, and inulin in reduced fat and salt Bologna sausage containing MDCM regarding technological, microstructural, nutritional, microbial, and sensorial properties along 60 days of shelf life.

\section{MATERIAL AND METHODS}

\subsection{Development of EG}

EG was prepared as reported previously ${ }^{20}$ with $4 \%$ soy protein (Dupont ${ }^{\circledR}$ Brazil), $50 \%$ soybean oil ( Liza $^{\circledR}$ Brazil), 16.5\% inulin (ORAFTI GR, Clariant, USA), and 29.5\% water.

\subsection{Design and manufacture of Bologna sausages}

Fresh pork longissimus dorsi muscle $(72.2 \%$ moisture, $6.4 \%$ fat, $19.6 \%$ protein, and $1.9 \%$ ash), pork back fat ( $11.6 \%$ moisture, $84.2 \%$ fat, $3.6 \%$ protein, and $0.6 \%$ ash), and 
mechanically deboned chicken meat (68.4\% moisture, $16.6 \%$ fat, $14.4 \%$ protein, and $1.2 \%$ ash), were obtained from a local marketplace in Campinas, SP. The pork meat was prepared by removing visible fat and connective tissue. The pork meat and pork back fat were grounded into $5 \mathrm{~mm}$ discs and then packed in vacuum and kept at $-20^{\circ} \mathrm{C}$ until their use.

Eight different batches of $6 \mathrm{~kg}$ were formulated according to Felisberto et al. ${ }^{14}$ Table 1. Bolognas were prepared in a cutter (MTK and 661 model, Mado, Germany) and embedded into impermeable cellulose casings (Viskase, $5.5 \mathrm{~cm}$ diameter) and package with approximately $200 \mathrm{~g}$ of batter per pieces. The cooking process was performed in a water bath (RSA 1708, RSA, Campinas, Brazil) gradually increasing the temperature until the sample core reached $72-74^{\circ} \mathrm{C}(\sim 1 \mathrm{~h})$. The pieces were cooled in an ice bath (approximately $15 \mathrm{~min}$ ) and kept at $4{ }^{\circ} \mathrm{C}$. All samples were analyzed regarding to technological properties during shelf life $\left(0,15,30,45\right.$, and 60 days of storage at $\left.4{ }^{\circ} \mathrm{C}\right)$. Microbiological and sensorial properties (day 10 of storage at $4{ }^{\circ} \mathrm{C}$ ) were evaluated for PF20/NS (pork back fat 20\%/normal salt), EG20/NS (emulsion gel 20\%/normal salt 2\%), EG20/RS (emulsion gel 20\%/reduced salt - 1\%), PF10-EG10/NS (pork back fat $10 \%$ emulsion gel $10 \%$ /normal salt $-2 \%$ ), and PF10-EG10/RS (pork back fat $10 \%$ emulsion gel 10\%/reduced salt -1\%) treatments. 


\subsubsection{Bologna sausagesEmulsion stability}

The stability of the emulsion was performed according to Colmenero et al. ${ }^{21}$ The total amount of fluid released containing water and fat from the raw sausage was expressed as a percentage in relation to initial weight of the batter. The analysis was carried out in five replicates.

\subsection{Bologna sausages analysis}

\subsubsection{Proximate analysis, sodium content and energy value}

Protein, ash, moisture contents and sodium content were performed according to $\mathrm{AOAC}^{22}$ at day 0 . Bligh and $\mathrm{Dyer}^{23}$ method was used to quantify fat content. From supplier data, the total dietary fiber (TDF) of inulin was estimated. Sodium content was measured with an inductively coupled plasma optical emission spectrometer (ICP OES) (Vista MPX, Varian, Mulgrave, Australia). The ICP OES operating conditions were: 1000 W of potency; $0.9 \mathrm{~L} / \mathrm{min}$ of nebulizing rate; 1.5 and $15 \mathrm{~L} / \mathrm{min}$ of flow rate of argon and the auxiliary gas, respectively; 10 and $3 \mathrm{~s}$ of integrating and reading times, respectively. $\Lambda(\mathrm{nm})$ used for sodium was 589.592 . Values of $9 \mathrm{kcal} / \mathrm{g}$ for fat; $4 \mathrm{kcal} / \mathrm{g}$ for protein and carbohydrate and $2 \mathrm{kcal} / \mathrm{g}$ for dietary fiber were used to calculate energy content. All analysis were performed in triplicate. 


\subsubsection{Fatty acid profile - FAP}

FAP was performed as reported by Paglarini et al. ${ }^{18}$ by using a GC with a capillary column (CGC 68650 Series GC System, Agilent, Santa Clara, California, USA) equipped with a flame ionization detector. ${ }^{24}$ The methyl esters of fatty acids were separated on Agilent DB-23 capillary column (50\% cyanopropyl-methylpolysiloxane), dimensions $60 \mathrm{~m}, \varnothing$ int: $0.25 \mathrm{~mm}, 0.25 \mu \mathrm{m}$ film.

Atherogenic (AI) was calculated by using the equation (C12:0 $+4 \times \mathrm{C} 14: 0+\mathrm{C} 16: 0) /$ (C16:1, C17:1, C18:1n-9, C20:1, C18:2n-6, and C18:3n-3)) and thrombogenic index (TI) $(C 14: 0+C 16: 0+C 18: 0) /[(0.5 \times$ MUFA $)+(0.5 \times \Sigma n-6)+(3 \times \Sigma n-3)+(\Sigma n-3 / \Sigma n-6)] .{ }^{25}$

\subsubsection{Instrumental $\mathrm{pH}, \mathrm{a}_{w}$ and color}

A Mettler Toledo $\mathrm{pH}$ meter (Columbus, $\mathrm{OH}$, United States) was used to measure $\mathrm{pH}$. The water activity (aw) was analyzed with an Aqua lab CX-2 water-activity meter (Decagon Devices, Inc., Pullman, WA). CIELab L*, $a^{\star}$, and $b^{*}$ were carried out using a CM-5 spectrophotometer (Konica Minolta, Tokyo, Japan), working with D65 illuminant, $10^{\circ}$ observer angle and SCE mode. Euclidean distance $(\Delta \mathrm{E}=$ $\left.\sqrt{\left(L_{P F 20 / N S}^{*}-L_{R}^{*}\right)^{2}+\left(a_{P F 20 / N S}^{*}-a_{R}^{*}\right)^{2}+\left(b_{P F 20 / N S}^{*}-b_{R}^{*}\right)^{2}}\right)$ was calculated to evaluate the difference between control (PF20/NS) and reduced salt and/or fat sausages -R (PF20/RS, PF10/NS, PF10/RS, EG20/RS, EG20/NS, PF10-EG10/NS, PF10-EG10/RS). Analyses were performed at days $0,15,30,45$ and 60 in triplicate. 


\subsubsection{Juiciness}

Juiciness was performed according to the method proposed by Lucherk et al. ${ }^{26}$ with some changes. Three cubes (dimensions $1 \times 1 \mathrm{~cm}$ ) were taken from the middle of Bologna pieces. Cubes were individually weighed on 2 sheets of qualitative filter paper (Unifil, $9 \mathrm{~cm}$ ) previously stored in a desiccator. Samples were compressed for $30 \mathrm{~s}$ at 78.45 N with a texture analyzer (TA-xT2i Texture Technologies Corp., Scarsdale, NY), and filter paper was reweighed without sample. Juiciness was expressed as the \% of fluid released from the sample during compression. The analysis was performed in triplicate at days $0,15,30,45$ and 60 of storage time.

\subsubsection{Texture profile analysis (TPA)}

TPA was determined at $4{ }^{\circ} \mathrm{C}$ using TA-xT2i texture analyzer (Texture Technologies Corp., Scarsdale, NY). Nine samples $(2 \mathrm{~cm}$ thick and $2 \mathrm{~cm} \varnothing)$ of each treatment were submitted to two successive compression cycles ( $5 \mathrm{~s}$ between them) at $30 \%$ of their original thickness, speed of $1 \mathrm{~mm} / \mathrm{s}$, using a P-35 probe (stainless steel, $35 \mathrm{~mm}$ in diameter). The parameters of hardness (expressed in N), springiness, chewiness, and cohesiveness were measured at $0,15,30,45$ and 60 days of storage time.

Lipid oxidation Thiobarbituric acid reactive substances (TBARS) were determined as proposed by Bruna et al. ${ }^{27}$ The measurements were taken at $\Lambda$ of $532 \mathrm{~nm}$ using a 
spectrophotometer (Beckman, Model DU-70, Muskegon, USA). Results were presented as mg of malondialdehyde (MDA)/kg of sample and obtained from a standard curve of TEP (1,1,3,3-tetraethyoxypropane). The analysis was carried out at 0, 15, 30, 45 and 60 days of storage time in quintuplicate.

\subsubsection{Scanning Electron Microscopy (SEM)}

The microstructure of the samples was evaluated according our previous study ${ }^{18}$ using a TM 3000 Tabletop Microscope (Hitachi High Technologies, Japan). 10 micrographs of two batches of each sample were taken at day 10 .

\subsubsection{Microbiological analysis}

The total mesophilic aerobic bacteria (total viable count), total and thermotolerants coliforms, psychrotrophic bacteria, and lactic acid bacteria were quantified according to the methodology proposed by Compendium of Methods for the Microbiological Examination of Food $^{28}$ at days $0,15,30,45$ and 60 of storage time. Two pieces of Bologna were used per treatment, and the analyses were performed in duplicate. From 8 formulations of Bologna sausages 5 were selected to microbiological analysis (PF20/NS, EG20/NS, EG20/RS, PF10-EG10/NS, and PF10-EG10/RS). The criterion to select then was samples with added EG and a control to compare. 


\subsubsection{Low-field NMR spin-spin relaxation (T2) measurements}

Water holding was investigated by measuring the NMR relaxation time T2 of the Bologna sausages after storage for 0,30 and 60 days, according our previous study. ${ }^{29}$ The measurements were performed utilizing a Bruker Minispec MQ20 NMR analyzer (Bruker Company, Tucson, USA) with $20 \mathrm{MHz}$ of proton resonance frequency using approximately $1 \mathrm{~g}$ of the sample per replicate.

\subsubsection{Sensory analyses}

Sensory profile of Bologna was performed at the Laboratory of Sensory Analysis of the Institute of Food Engineering (FEA) - UNICAMP. Each sample (approximately 3 g, 5$10^{\circ} \mathrm{C}$ ) was placed on plastic cups, labeled and presented in a balanced presentation order. ${ }^{30}$ From 8 formulations of Bologna sausages 5 were selected to sensory analysis. The criterion to select then was samples with added EG and a control to compare. The Bolognas samples were evaluated by 120 untrained assessors ( 40 men, 80 women, aged 18-66) and the selection criterion was regular consumption of meat products.

\subsubsection{Acceptance test and Purchase intention}

Consumers were asked to evaluate the parameters aroma, color, flavor, texture, aroma, and overall liking on a hedonic scale from $1=$ disliked extremely to $9=$ liked extremely. We have included a purchase intention question using a 5 -point scale from $1=$ would certainly not buy to $5=$ would certainly buy. 


\subsubsection{2 . Check-all-that-apply questions}

19 descriptors linked to the sensory properties of Bolognas were evaluated by consumers in CATA questionnaire. The selection of the descriptors was based on previous studies performed in our laboratory (Meat and Meat products Laboratory, FEA/UNICAMP, Brazil). The sensory attributes appearance (pale color, and ideal color), flavor (spicy, oil, little spicy, juicy, mild, greasy, Bologna, salty, low salt, and salt in the right amount), texture (spongy, gritty, firm, rubbery, and soft), and aroma (Bologna, and mild), were used to describe the sensory profile of the Bolognas.

\section{$2.4 \quad$ Statistical analyses}

The experimental design was performed in three replicates by using a randomized block design. The differences between samples (except CATA data) were evaluated by analysis of variance using a General Linear Model (GLM) taking the treatments and storage time as fixed effect and the replicates as random effect by Tukey's test ( $p<$ 0.05). The trial version of Statistica 13 (Statsoft ${ }^{\circledR}$, Dell software, Califórnia, EUA) was used.

CATA questionnaire was first analyzed by counting the frequency of mentioning each sensory descriptor for Bolognas, ${ }^{31}$ and a nonparametric Cochran's $Q$ test was performed to detect significant differences between samples for each attribute. 
Afterwards, correspondence analysis (CA) was executed considering the Chi-square distances $^{32}$ and principal coordinate analysis was performed to correlate sensory attributes and overall liking using XLSTAT 2018 free trial (Addinsoft, New York, USA). Three samples per batch were analysed for the physicochemical and technological analysis. For sensorial evaluation, each panelist tasted five samples, one from each formulation, in a single session.

\section{Results and discussion}

\subsection{Composition}

As presented in Table 2, simple fat reduction strategy (PF10/NS and PF10/RS) caused an increase in the moisture content of the samples. Samples with EG (EG20/NS and EG20/RS) also presented higher moisture content than control normal fat ones ( $p<$ 0.05) probably due to the water addition in the EG formulation.

A fat reduction of approx. 21\% was reached in Bolognas with EG (EG20/NS and EG20/RS) and approx 12\% in Bologna with EG and animal fat (PF10-EG10/NS and PF10-EG10/RS). EG added in Bologna sausage slightly affected protein content. Reduced sodium products (PF20/RS, PF10/RS, EG20/RS, and PF10-EG10/RS) presented lower ash content than normal salt ones $(p<0.05)$, as expected. Generally, a sodium reduction of $39 \%$ was reached falling in the "reduced sodium" category. ${ }^{33}$

A calculated dietary fiber content of $2.97 \%$ for EG20/NS and EG20/RS allows these samples to be labeled as "good source of fiber" by American rules. ${ }^{34} \mathrm{~A}$ reduction of 
approx. 16 and 9\% in energy value of EG and EG+PF sausages, respectively, was obtained compared to controls samples (PF20/NS and PF20/RS). Samples with 10\% of EG presented an estimated dietary fiber of $1.49 \%$.

\subsection{Juiciness and Emulsion stability}

Related to juiciness values (Fig 1), reduced salt and fat sample (PF10/RS) presented higher values during all shelf life. Normal fat (PF20/NS and PF20/RS) and samples with added EG+PF (PF10-EG10/NS and PF10-EG10/RS) were less juicy during shelf life comparing to other ones $(p<0.05)$.

Reduced fat samples presented higher value of juiciness in the day 15 of shelf life and normal fat samples in the days 30 and 45 of chilled storage $(p<0.05)$. Samples from treatments with salt reduction generally presented higher value of juiciness than others. An unexpected result because one of the main functions of salt is to solubilize the functional myofibrillar proteins of meat and consequently increase juiciness in meat product. ${ }^{35}$ It is important to highlight that control treatment (PF20/NS) showed values of juiciness close to samples with EG (Fig 1).

For the emulsion stability, a similar trend as for juiciness was observed. Bologna sausage with fat and salt reduction simultaneously (PF10/RS) released more liquid along the storage between all treatments while Bologna with EG (EG20/NS) was the most stable sample $(p<0.05)$ (Figure 1$)$. MDCM is a meat ingredient commonly used to 
produce low cost meat products with protein level (approx. 14\%) lower than lean muscle meat (20-24\%). During production of MDCM a part of the myofibrillar proteins is damaged resulting in loss of functionality. ${ }^{36}$ For these reasons, salt and fat reduction affects the quality of the final products resulting in a larger amount of liquid released during the cooking process. However, when emulsion gel was added to meat emulsion (EG20/NS, PF10-EG10/NS) the liquid released was close to zero probably due to the water and fat holding capacity of the hydrocolloids (especially inulin) added to the emulsion gels. ${ }^{8,37}$

\subsection{Fatty acid profile}

The fatty acid profile of Bologna sausages was improved in all treatments containing soybean oil as the lipid phase in EGs as can be observed in Table 3. A reduction of 47 and $25 \%$ of SFA and an increase of 87 and $42 \%$ of PUFA was reached for $100 \%$ and $50 \%$ substitution of pork back fat by EG, respectively (EG20/NS, EG20/RS, PF10EG10/NS, and PF10-EG10/NS). In these samples, more than $70 \%$ of total fatty acids are unsaturated and it provides more than $20 \%$ of total energy of the product; then sausages could be considered as "high content unsaturated lipids". ${ }^{38}$ These results are in according to Wolfer et al. ${ }^{39}$ studying the replacement of pork back fat in frankfurtertype sausages by soybean oil oleogels structured with rice bran wax.

Although soybean oil is not a good source of $n-3$ if compared to the other vegetal oils such as canola and linseed, ${ }^{40}$ values n-3 were increased from 2.36 (PF20/NS and RS) 
to 7.38 and $4.84 \mathrm{~g} / \mathrm{kg}^{-1}$ product (EG20 and PF10-EG10, respectively). EG20 samples had more than $0.6 \mathrm{~g} \mathrm{n}-3 / 100 \mathrm{~g}$ product, which allows these products to be labeled as "rich in omega 3" by European legislation. ${ }^{38}$ This oil has been selected for the emulsion gel formulations to be added as fat substitute in meat products ${ }^{19}, 41$ mainly due its healthier fatty acid composition (compared to pork back fat) and its high availability which reduces the cost of the final product. It seemed more compatible with the one of the most principal objectives or our work that is reformulating a low-cost formulation of Bologna sausage characterized by adding of 50\% MDCM, a high value-added raw material widely used along the word. The searching for feasible strategies to reformulate meat products to be accessible to different target groups could effectively contribute to improve the nutritional status of population, including that one with low income. Then, despite the addition of EG reducing values of $n-6 / n-3$ ratio, they are still higher than the recommendations to be lower than $4 .{ }^{42}$

Related to PUFA/SFA ratio, the addition of EG in sausages increased significantly these values, indicating a better nutritional profile (Table 3). Previous studies that added structured vegetable oil to replace animal fat in meat products also indicated an improvement in PUFA/SFA ratio. ${ }^{7}$ A regular consumption of foods with a PUFA/SFA ratio lower than 0.45 may increase the occurrence of cardiovascular diseases. ${ }^{43}$ Thrombogenic and atherogenic index (potential promoters of platelet aggregation) were also improved by EG addition. To maintain human health through the prevention of 
coronary heart disease values for the $\mathrm{Al}$ and $\mathrm{TI}$ indexes, at 1 and 0.5 , respectively, are expected. ${ }^{44}$ Table 3 shows that only samples with EG (EG20/NS and EG20/RS) reached desirable values of $\mathrm{TI}$ and Al simultaneously.

3.4 $\mathrm{pH}, \mathrm{a}_{\mathrm{w}}$, TBARS, and color $\left(\mathrm{L}^{*}, \mathrm{a}^{*}, \mathrm{~b}^{*}\right)$ parameters of reformulated Bologna sausages

The $\mathrm{pH}$ values (Table 4) of Bolognas were affected by formulation and by chilled storage $(p<0.05)$, although typical values of $\mathrm{pH}$ for meat emulsion were found $(6.13$ to 6.46). In general reduced salt products presented higher $\mathrm{pH}$ values than normal salt samples $(p<0.05)$. Control (PF20/NS) and EG added treatments presented similar values of $\mathrm{pH}(\mathrm{p}>0.05)$, except in the day 60 of storage when control sample (PF20/NS) presented higher values. Similar $\mathrm{pH}$ range was reported previously when EG was added as fat substitute in frankfurter. ${ }^{45}$

$A_{w}$ values ranged from 0.970 to 0.985 and the reduction of sodium and animal fat simultaneously (PF10/RS, EG20/RS and PF10-EG10/RS) increased aw in the samples $(p<0.05)$. During shelf life, $a_{w}$ reached the higher values at day 60 for samples PF10/NS, PF10/RS, EG20/NS, EG20/RS, PF10-EG10/NS, and PF10-EG10/RS. In general, EG addition (EG20/NS, PF10-EG10/NS) do not affected aw values comparing to control treatment (PF20/NS), with aw values typical of emulsified meat products. ${ }^{46} \mathrm{An}$ interesting finding due to the importance of aw for food quality and safety. 
TBARS values of reformulated Bologna sausages ranged from 0.04 to $0.89 \mathrm{mg} \mathrm{MDA} / \mathrm{kg}$ sample (Table 4) during chilled storage. It was observed that EG addition affected lipid oxidation in Bologna sausages. A more intense oxidation was perceived in EG added samples (EG20/NS and EG20/RS), followed by EG+PF (PF10-EG10/NS and PF10EG10/RS) $(p<0.05)$. This increase in lipid oxidation was expected due to the higher concentration of PUFAs in treatments containing soybean oil as lipid phase of EGs when compared to controls added of pork back fat (Table 3), in accordance with previous studies. ${ }^{43}$ According to Choi et al. ${ }^{47}$ different oils increase oxidation levels of frankfurters. Soybean oil was more prone to oxidation than pork back fat, olive oil, grape seed oil, corn oil, and canola oil in frankfurters.

During chilled storage, lipid oxidation remained steady until 30 days, with very similar results, not superior to $0.12 \mathrm{mg} \mathrm{MDA} / \mathrm{kg}$ sample. However, at 45 and 60 day, the TBARS values decreased for all treatments $(p<0.05)$ as opposed to reported in the literature by some authors. ${ }^{8,48,49}$ One possibility to explain these results it the reducing levels of malonaldehyde (MDA) precursors, during the secondary phase of the autoxidation process due to evolution of lipid oxidation. ${ }^{50,51}$ However, it should be followed of a sensory degradation of the products causing consumer rejection, which has not happened in our study. Zhang et al., ${ }^{52}$ regarding this point, investigated different TBARs methods aiming to correlate the data obtained to consumer study. The author shown there were no significant effects of TBARS values on the sensory results, 
suggesting that untrained consumers cannot detect abnormal flavour development due to high levels of lipid oxidation (TBARS) as indicated by the TBARS test. Regardless of the differences in meat matrix, besides the use of nitrite in our treatments that could contribute for this decreasing along the time, the lipid oxidation investigation appears as a great point to be understood.

Despite these considerations, TBARS values near $0.5 \mathrm{mg} / \mathrm{kg}$ sample suggested beginning of oxidation, and values above $1.0 \mathrm{mg} / \mathrm{kg}$ sample are indicative of advanced oxidative status. ${ }^{53}$ Then, all reformulated sausage presented values of TBARS lower than sensory rancidity detection (<1.0). Wang et al. ${ }^{48}$ reported that in emulsion gel, unsaturated oil is "structured" and the mobility of the reactants is restricted indicating why using EG is more suitable than adding the oil in a liquid form to guarantee a good oxidative stability. The addition of emulsion in different types of meat products as fat replacers have shown similar results, with TBARS values lower than $1.0 \mathrm{mg}$ MDA $/ \mathrm{kg}$ sample..$^{5,7,45}$

Color parameters (Table 4) show that control treatment (PF20/NS) presented lower values of lightness $\left(L^{*}\right)$ and higher values of $a^{*}$ than others $(p<0.05)$. $L^{*}$ values were higher $(p<0.05)$ in all EG added samples (EG20/NS, EG20/RS, PF10-EG10/NS, PF10EG10/RS). In general, storage time did not affect the color of samples ( $p>0.05)$. Values of Euclidian distance $(\Delta \mathrm{E})$ between 2 and 3.5 are an indicative that an inexperienced observer is able to perceive the difference while values among 3.5 and 5 
every observer can easily see the difference. ${ }^{54}$ Therefore, EG added samples were the most different samples comparing to PF20/NS treatment and can be easily differentiated from control by observer. These could be attributed to the ingredients used to form the emulsion gel (inulin, soy protein and soybean oil), given that the use of emulsion gel instead of animal fat does not perfectly mimic the color effect of pork back fat on the reformulated sausages. Color parameters of meat products are in general affected by emulsion gel addition. Barros et al. ${ }^{5}$ and Wang et al. ${ }^{48}$ also found an increase in $L^{*}$ values when adding emulsion gel as a fat substitute in beef burgers and cooked style Harbin sausage, respectively.

\subsection{Texture profile analysis (TPA) of reformulated Bologna sausages}

Substituting pork back fat (PF) by EG in the Bologna sausages decreased the hardness $(p<0.05)$ while products with only fat and salt reduction (PF10/NS and PF10/RS) were softer and chewy $(p<0.05)$ than others (Table 5). This behavior indicates that replacing fat by EG seems to be a better strategy than only fat reduction without EG. Results reported in literature show that salt reduction decreases hardness in meat product, ${ }^{55}$ however in this study fat reduction appeared to affect hardness more than salt reduction. During shelf life samples get harder for all treatments $(p<0.05)$, similar that was observed by other authors. ${ }^{56}$ 
Sausages with EG (EG20/NS, EG20/RS) were more elastic and cohesive than control (PF20/NS) $(p<0.05)$ during the storage. In general, springiness was not affected by storage time and samples get more cohesive during shelf life (Table 5).

3.6 Microstructural and time domain NMR (TDNMR) results of reformulated Bologna sausage

Figure 2 shows that Bologna sausage with EG (EG20/NS and EG20/RS) exhibited a denser network, presentation a more continuous and compact matrix in accordance with previous studies. ${ }^{57}$ When EG was added to replace partially PF the matrix presented structure similar to control treatment (Fig 2).

Sausages with salt reduction (PF20/NS, PF10/RS, EG20/RS, and PF10-EG10/RS) presented more empty spaces, probably due higher amount of free water in these samples, in accordance with emulsion stability data (Fig 1) when comparing samples with normal and reduced salt (for example, PF20/NS and PF20/RS, EG20/NS and EG20/RS) the reduced salt sample always released more liquid than normal salt one.

Figure 3-a shows that TDNMR $T_{2}$ relaxation curves for Bologna sausages presented a multiple-exponential distribution with clearly two distinct populations mainly related to water because about $80 \%$ of protons present in the meat samples comes from water. Entrapped or immobilized water $\left(T_{2 a}\right)$ presented a relaxation time between 10 and 100 $\mathrm{ms}$ and is linked to the highly organized protein or fiber bundles structures. While mobile water $\left(T_{2 b}\right)$ with relaxation time from 100 to $1000 \mathrm{~ms}$ refers to the water located between 
fiber bundles interacting weakly with charged group, also known as the extra-myofibrillar water containing the sarcoplasmic protein fraction. ${ }^{58}$

The distribution of relaxation times in immobilized water ( $\left.T_{2 a}\right)$ (Fig 3b, Supplementary Material 1) showed a higher time when the fat and salt content was reduced (see samples PF10/NS and PF10/RS), $p<0.05$. It can be associated with the increase in the mobility or the reduction of the interaction between mobility and the organized protein or fiber bundles structures. This result suggest that occurs an increasing in spaces that hold water as the fat and salt content was decreased in the Bologna sausages. According to Han et al. ${ }^{59}$ a shorter T2a may reflects a smaller size of the intrinsic structures in which the myofibrillar water is trapped and/or the local myofibrillar structures act as stronger relaxation sinks on the water molecules. However, with EG added treatments the values of time is recovered to near the controls probably by the fibers of the emulsion to make in parts the role of the fat, results similar to those obtained by juiciness and scanning electron microscopy evaluation. Comparing with texture data, especially for samples PF10/NS and PF10/RS, higher values of $\mathrm{T}_{2} \mathrm{a}$ and lower values of hardness were obtained for these samples. The negative correlation between hardness and T2a values was also observed by García et al. ${ }^{60}$.

The behavior observed in mobile population ( $\left.T_{2 b}\right)$ (Fig 3b, Supplementary Material 1 ) shows a fluctuation in the average, might because change in the composition does not cause a sudden change in this population. These results suggested that mobile water is 
not sensitive to changes occurring in the composition mainly because it is weakly bound to the matrix. In general control Bologna (PF20/NS) showed the lowest values of $T_{2 b}(p$ $<0.05)$.

Now probing the quantities of the two distinct populations, except for shelf life 15 days, it has a higher amount of mobile water population $\mathrm{T}_{2 b}$ compared to immobilized water $\mathrm{T}_{2 a}$ for the treatments control and with EG. On other hand, in the PF10/NS and PF10/RS samples this proportion was inverted $(p<0.05)$. This can probably be ascribed to the fat and salt reduction causing poor interaction (or increase of water holes) and for this reason is easier to remove mobile water. However the EG addition recovers the matrix that has been weakened due to reduction of fat and salt.

\subsection{Microbiological properties of reformulated Bologna sausage}

Total viable count (mesophilic colonies) remained low ( $<3.5$ log cfu/g) during chilled storage of Bologna sausages (Table 6). In general sample with salt reduction and EG addition presented the largest number of colonies (EG20/RS) $(p<0.05)$. Salt is an important ingredient in meat products ensuring microbiological stability mainly through water activity reduction. ${ }^{61}$ Lactic acid and psychrotrophic bacteria levels were lower than $1 \mathrm{log} \mathrm{cfu} / \mathrm{g}$ and for coliforms was $<3 \mathrm{NMP} / \mathrm{g}$, (data not shown). These low levels of microorganism could be associated with the additives and seasonings added to the 
Bolognas formulation and also good manufacturing practices ensuring that the product was safe for consumers.

\subsection{Sensorial properties of reformulated Bologna sausages}

As can be seen in Figure 4 all samples were judged acceptable (scores higher than 5). Excepting for color, no statistical difference $(p>0.05)$ were found between control (PF20/NS) and Bolognas with EG+PF with no salt reduction (PF10-EG10/NS) for texture, flavor, aroma, and overall liking. Samples with simultaneously salt and fat reduction and the addition of EG (EG20/RS and PF10-EG10/RS) scored lowest when compared to others samples in agreement with previous studies that have also found the negative impact that the reduction of fat and salt have on the sensory characteristics of emulsified meat products. ${ }^{62}$ Regarding purchase intention, samples presented 3.7, 3.0, 2.5, 3.6, and 2.90 scores for PF20/NS, EG20/NS, EG20/RS, PF10-EG10/NS, and PF10-EG10/RS, respectively.

The nonparametric Cochran's Q test was performed, and it shows that there were significant differences for 16 of 19 descriptors used to characterize the samples. Descriptors with less than $10 \%$ of frequency's mention were also removed.

By correspondence analysis (Figure 4b) three groups of samples with different sensory characteristics were perceived. The first group PF20/NS and PF10-EG10/NS were close to the descriptors firm, juicy, ideal color, right amount of salt, Bologna flavor, 
Bologna aroma, and spicy flavor. According to Desmond ${ }^{35}$ normal salt products are juiciest than reduced ones due to salt increase water holding capacity. The second group PF10-EG10/RS and EG20/RS were linked to mild aroma, low salt, little spicy, mild flavor, and pale color descriptors.

The third group was composed by EG20/NS sample, characterized as spongy, greasy, and with oil flavor. Overall liking attribute (Figure 4c) was associated to firm, Bologna flavor, juicy, ideal color, and right amount of salt descriptors, attributes characteristics of PF10-EG10/NS and PF20/NS samples.

When emulsion gel was applied as a fat replacer, sensorial results shown that the perception of flavor and aroma compounds was reduced. Previous studies shown that aroma compounds had lower released in systems more compact like emulsion gels. ${ }^{63,64}$

\section{Conclusion}

This study has demonstrated the potential use of inulin-based emulsion gel as a fat substitute in reduced fat and salt meat products. Replacing pork back fat by EG resulted in products with higher fiber content and a better fatty acid profile with higher amount of unsaturated fatty acids and lower content of SFA. The addition of EG makes sample more stable to heat treatment while microbiological and sensorial data were negatively impacted by simultaneously salt and fat reduction in Bologna sausage with EG. The shelf life study shown that samples with EG presented good results related to lipid 
oxidation and NMR data, presenting alterations in textural and microstructural properties when compared to control. Bologna with EG seems to be a good option to obtain healthier meat product, and future studies are need to improve the properties when salt and fat are reduced simultaneously.

\section{Conflict of interest}

The authors declare no conflict of interest associated with this research.

\section{Acknowlegments}

The authors are thankful to CNPq (140531/2015-7), CAPES (140531/2015-7), and FAPESP (2016/ 19967-7) for providing financial support and scholarships that sustain this study. Authors wish to thanks CPKelco and Clariant, for the donation of SPI and inulin, respectively. We also are grateful to Maristela Ozaki, Andrea Paola, Giseli Magalhães, and Mirian Santos for their help during sensorial analysis.

\section{$7 \quad$ References}

1 Olmedilla-Alonso B, Jiménez-Colmenero F and Sánchez-Muniz FJ, Development and assessment of healthy properties of meat and meat products designed as functional foods. Meat Sci 95: 919-930 (2013). http://dx.doi.org/10.1016/j.meatsci.2013.03.030.

2 WHO. Interim Summary of Conclusions and Dietary Recommendations on Total Fat \& Fatty Acids. Report of a joint WHO/FAO expert consultation. Geneva (2008).

3 WHO. Guideline: Sodium intake for adults and children Geneva: World Health Organization (2012). 
4 Dickinson E, Emulsion gels: The structuring of soft solids with protein-stabilized oil droplets. Food Hydrocoll 28: 224-241 (2012). DOI: https://doi.org/10.1016/j.foodhyd.2011.12.017.

5 Carvalho Barros J, Munekata PES, de Carvalho FAL, Pateiro M, Barba FJ, Domínguez $\mathrm{R}$ et al., Use of Tiger Nut (Cyperus esculentus L.) Oil Emulsion as Animal Fat Replacement in Beef Burgers. Foods 9 (2020) 2020/01/18. DOI: 10.3390/foods 9010044 .

6 Alejandre M, Ansorena D, Calvo MI, Cavero RY and Astiasarán I, Influence of a gel emulsion containing microalgal oil and a blackthorn (Prunus spinosa L.) branch extract on the antioxidant capacity and acceptability of reduced-fat beef patties. Meat Sci 148: 219-222 (2019). DOI: https://doi.org/10.1016/j.meatsci.2018.05.022.

$7 \quad$ Alejandre M, Astiasarán I, Ansorena D and Barbut S, Using canola oil hydrogels and organogels to reduce saturated animal fat in meat batters. Food Res Int 122: 129136 (2019). DOI: https://doi.org/10.1016/j.foodres.2019.03.056.

8 Glisic M, Baltic M, Glisic M, Trbovic D, Jokanovic M, Parunovic N et al., Inulinbased emulsion-filled gel as a fat replacer in prebiotic- and PUFA-enriched dry fermented sausages. Int J Food Sci Technol 54: 787-797 (2019). DOI: 10.1111/ijfs.13996.

9 Paglarini CdS, Vidal VAS, dos Santos M, Coimbra LO, Esmerino EA, Cruz AG et al., Using dynamic sensory techniques to determine drivers of liking in sodium and fatreduced Bologna sausage containing functional emulsion gels. Food Res Int 132: 109066 (2020). DOI: https://doi.org/10.1016/j.foodres.2020.109066.

10 Molina E, Defaye AB and Ledward DA, Soy protein pressure-induced gels. Food Hydrocoll 16: 625-632 (2002). DOI: https://doi.org/10.1016/S0268-005X(02)00028-0.

11 Youssef MK and Barbut S, Effects of two types of soy protein isolates, native and preheated whey protein isolates on emulsified meat batters prepared at different protein levels. Meat Sci 87: 54-60 (2011). DOI: https://doi.org/10.1016/j.meatsci.2010.09.002.

12 Lo Wendy MY, Farnworth ER and Li-Chan ECY, Angiotensin I-Converting Enzyme Inhibitory Activity of Soy Protein Digests in a Dynamic Model System Simulating the Upper Gastrointestinal Tract. J Food Sci 71: S231-S237 (2006). DOI: doi:10.1111/j.1365-2621.2006.tb15646.x.

13 Poth U. Drying Oils and Related Products. Ullmann's Encyclopedia of Industrial Chemistry. (2001).

14 Felisberto MHF, Galvão MTEL, Picone CSF, Cunha RL and Pollonio MAR, Effect of prebiotic ingredients on the rheological properties and microstructure of reducedsodium and low-fat meat emulsions. LWT - Food Sci Technol 60: 148-155 (2015). DOI: http://dx.doi.org/10.1016/j.Iwt.2014.08.004.

15 Angiolillo L, Conte A and Del Nobile MA, Technological strategies to produce functional meat burgers. LWT - Food Sci Technol 62: 697-703 (2015). DOI: https://doi.org/10.1016/j.Iwt.2014.08.021. 
16 Bot A, Erle U, Vreeker R and Agterof WGM, Influence of crystallisation conditions on the large deformation rheology of inulin gels. Food Hydrocoll 18: 547-556 (2004). DOI: http://dx.doi.org/10.1016/j.foodhyd.2003.09.003.

17 Herrero AM, Carmona $\mathrm{P}$, Jiménez-Colmenero $\mathrm{F}$ and Ruiz-Capillas $\mathrm{C}$, Polysaccharide gels as oil bulking agents: Technological and structural properties. Food Hydrocoll 36: 374-381 (2014). DOI: http://dx.doi.org/10.1016/j.foodhyd.2013.08.008.

18 Paglarini CS, Furtado GF, Honório AR, Mokarzel L, Vidal VAS, Ribeiro APB et al., Functional emulsion gels as pork back fat replacers in Bologna sausage. Food Struct 20: 100105 (2019). DOI: https://doi.org/10.1016/j.foostr.2019.100105.

19. Paglarini CS, Martini $S$ and Pollonio MAR, Using emulsion gels made with sonicated soy protein isolate dispersions to replace fat in frankfurters. LWT - Food Sci Technol 99: 453-459 (2019). DOI: https://doi.org/10.1016/j.Iwt.2018.10.005.

20 Paglarini CS, Martini S and Pollonio MAR, Physical properties of emulsion gels formulated with sonicated soy protein isolate. International Journal of Food Science \& Technology 0 (2018). DOI: doi:10.1111/ijfs.13957.

21 Colmenero FJ, Ayo MJ and Carballo J, Physicochemical properties of low sodium frankfurter with added walnut: effect of transglutaminase combined with caseinate, $\mathrm{KCl}$ and dietary fibre as salt replacers. Meat Sci 69: 781-788 (2005). DOI: http://dx.doi.org/10.1016/j.meatsci.2004.11.011.

22 AOAC. Official methods of analysis of AOAC International. Gaithersburg, Md.: AOAC International (2005).

23 Bligh EG and Dyer WJ, A rapid method of total lipid extraction and purification Canadian J Biochem Physiol 37: 911-917 (1959). DOI: 10.1139/059-099.

24 Toldrá $\mathrm{F}$ and Reig M, Innovations for healthier processed meats. Trends Food Sci Technol 22: 517-522 (2011). DOI: https://doi.org/10.1016/j.tifs.2011.08.007.

$25 \quad$ Ulbricht TLV and Southgate DAT, Coronary heart disease: seven dietary factors. The Lancet 338: 985-992 (1991). DOI: 10.1016/0140-6736(91)91846-M.

26 Lucherk LW, O'Quinn TG, Legako JF, Rathmann RJ, Brooks JC and Miller MF, Assessment of objective measures of beef steak juiciness and their relationships to sensory panel juiciness ratings1,2. J Anim Sci 95: 2421-2437 (2017). DOI: 10.2527/jas.2016.0930.

27 Bruna JM, Ordóñez JA, Fernández M, Herranz B and de la Hoz L, Microbial and physico-chemical changes during the ripening of dry fermented sausages superficially inoculated with or having added an intracellular cell-free extract of Penicillium aurantiogriseum. Meat Sci 59: 87-96 (2001). DOI: http://dx.doi.org/10.1016/S03091740(01)00057-2.

28 Downes FP and Ito $\mathrm{H}$, Compendium of methods for the microbiological examination of foods. Washington: American Public Health Association, (2001).

29 Vidal VAS, Bernardinelli OD, Paglarini CS, Sabadini E and Pollonio MAR, Understanding the effect of different chloride salts on the water behavior in the salted 
meat matrix along 180 days of shelf life. Food Res Int 125: 108634 (2019). DOI: https://doi.org/10.1016/j.foodres.2019.108634.

30 Macfie HJ, Bratchell N, Greenhoff K and Vallis LV, Designs to Balance the Effect of Order of Presentation and First-Order Carry-over Effects in Hall Tests. J Sens Stud 4: 129-148 (1989). DOI: 10.1111/j.1745-459X.1989.tb00463.x.

31 Meyners M, Castura JC and Carr BT, Existing and new approaches for the analysis of CATA data. Food Qual Prefer 30: 309-319 (2013). DOI: https://doi.org/10.1016/j.foodqual.2013.06.010.

32 Vidal L, Tárrega A, Antúnez L, Ares G and Jaeger SR, Comparison of Correspondence Analysis based on Hellinger and chi-square distances to obtain sensory spaces from check-all-that-apply (CATA) questions. Food Qual Prefer 43: 106112 (2015). DOI: http://dx.doi.org/10.1016/j.foodqual.2015.03.003.

33 FDA. Food labeling. In: Service DoHaH, (ed.). Maryland: Food and Drug Administration (2018).

34 FDA. Food and Drug Administration. Health Claims; Soluble Dietary Fiber From Certain Foods and Coronary Heart Disease; Final Rule. In: Federal Register, (ed.). (2016).

35 Desmond E, Reducing salt: A challenge for the meat industry. Meat Sci 74: 188196 (2006). DOI: https://doi.org/10.1016/j.meatsci.2006.04.014.

36 Daros FG, Lucia Masson $\mathrm{M}$ and Amico SC, The influence of the addition of mechanically deboned poultry meat on the rheological properties of sausage. J Food Eng 68: 185-189 (2005). DOI: https://doi.org/10.1016/j.jfoodeng.2004.05.030.

37 Juszczak L, Witczak T, Ziobro R, Korus J, Cieślik E and Witczak M, Effect of inulin on rheological and thermal properties of gluten-free dough. Carbohydr Polym 90: 353-360 (2012). DOI: https://doi.org/10.1016/j.carbpol.2012.04.071.

38 EC. European Comission. Nutrition and health claims made on foods. Regulation (EC) $n$ 1924/2006 of the European parliament and of the council. In: Official Journal of the European Union L-L, (ed.) (2006).

39 Wolfer TL, Acevedo NC, Prusa KJ, Sebranek JG and Tarté R, Replacement of pork fat in frankfurter-type sausages by soybean oil oleogels structured with rice bran wax. Meat Sci 145: 352-362 (2018). DOI: https://doi.org/10.1016/j.meatsci.2018.07.012. 40 Dubois V, Breton S, Linder M, Fanni J and Parmentier M, Fatty acid profiles of 80 vegetable oils with regard to their nutritional potential. Eur J Lipid Sci Technol 109: 710732 (2007). DOI: 10.1002/ejlt.200700040.

41 Paglarini CS, Furtado GF, Biachi JP, Vidal VAS, Martini S, Forte MBS et al., Functional emulsion gels with potential application in meat products. J Food Eng 222: 29-37 (2018). DOI: https://doi.org/10.1016/j.jfoodeng.2017.10.026.

42 Bernardi DM, Bertol TM, Pflanzer SB, Sgarbieri VC and Pollonio MAR, $\omega-3$ in meat products: benefits and effects on lipid oxidative stability. J Sci Food Agric 96: 2620-2634 (2016). DOI: 10.1002/jsfa.7559. 
43 Heck RT, Saldaña E, Lorenzo JM, Correa LP, Fagundes MB, Cichoski AJ et al., Hydrogelled emulsion from chia and linseed oils: A promising strategy to produce lowfat burgers with a healthier lipid profile. Meat Sci 156: 174-182 (2019). DOI: https://doi.org/10.1016/j.meatsci.2019.05.034.

44 Fernandes CE, Vasconcelos MA, Ribeiro Mde A, Sarubbo LA, Andrade SA and Filho $A B$, Nutritional and lipid profiles in marine fish species from Brazil. Food Chem 160: 67-71 (2014) 2014/05/07. DOI: 10.1016/j.foodchem.2014.03.055.

45 Pintado T, Herrero AM, Jiménez-Colmenero $F$ and Ruiz-Capillas C, Strategies for incorporation of chia (Salvia hispanica L.) in frankfurters as a health-promoting $\begin{array}{lllll}\text { ingredient. } \quad \text { Meat Sci 114: 75-84 (2016). DOI: } & \end{array}$ https://doi.org/10.1016/j.meatsci.2015.12.009.

46 da Silva SL, Amaral JT, Ribeiro M, Sebastião EE, Vargas C, de Lima Franzen F et al., Fat replacement by oleogel rich in oleic acid and its impact on the technological, nutritional, oxidative, and sensory properties of Bologna-type sausages. Meat Sci 149: 141-148 (2019). DOI: https://doi.org/10.1016/j.meatsci.2018.11.020.

47 Choi Y-S, Choi J-H, Han D-J, Kim H-Y, Lee M-A, Jeong J-Y et al., Effects of replacing pork back fat with vegetable oils and rice bran fiber on the quality of reduced$\begin{array}{lllll}\text { fat frankfurters. Meat Sci 84: 557-563 (2010). DOI: } & \end{array}$ https://doi.org/10.1016/j.meatsci.2009.10.012.

48 Wang X, Xie Y, Li X, Liu Y and Yan W, Effects of partial replacement of pork back fat by a camellia oil gel on certain quality characteristics of a cooked style Harbin sausage. Meat Sci 146: 154-159 (2018). DOI: https://doi.org/10.1016/j.meatsci.2018.08.011.

49 Özer CO and Çelegen Ş, Evaluation of quality and emulsion stability of a fatreduced beef burger prepared with an olive oil oleogel-based emulsion. $J$ Food Process Preserv n/a: e14547 (2020). DOI: 10.1111/jfpp.14547.

50 Guillén-Sans R and Guzmán-Chozas M, The Thiobarbituric Acid (TBA) Reaction in Foods: A Review. Crit Rev Food Sci Nutr 38: 315-350 (1998). DOI: 10.1080/10408699891274228.

51 Domínguez R, Pateiro M, Gagaoua M, Barba FJ, Zhang W and Lorenzo JM, A Comprehensive Review on Lipid Oxidation in Meat and Meat Products. Antioxidants 8: 429 (2019).

52 Zhang Y, Holman BWB, Ponnampalam EN, Kerr MG, Bailes KL, Kilgannon AK et al., Understanding beef flavour and overall liking traits using two different methods for determination of thiobarbituric acid reactive substance (TBARS). Meat Sci 149: 114-119 (2019). DOI: https://doi.org/10.1016/j.meatsci.2018.11.018.

53 Reitznerová A, Šuleková M, Nagy J, Marcinčák S, Semjon B, Čertík M et al., Lipid Peroxidation Process in Meat and Meat Products: A Comparison Study of Malondialdehyde Determination between Modified 2-Thiobarbituric Acid 
Spectrophotometric Method and Reverse-Phase High-Performance Liquid Chromatography. Molecules 22: 1988 (2017).

54 Pielak M, Czarniecka-Skubina E and Głuchowski A, Effect of Sugar Substitution with Steviol Glycosides on Sensory Quality and Physicochemical Composition of LowSugar Apple Preserves. Foods 9 (2020) 2020/03/11. DOI: 10.3390/foods9030293.

55 Pietrasik $Z$ and Gaudette NJ, The effect of salt replacers and flavor enhancer on the processing characteristics and consumer acceptance of turkey sausages. J Sci Food Agric 95: 1845-1851 (2015). DOI: doi:10.1002/jsfa.6885.

56 Pintado T, Herrero AM, Ruiz-Capillas C, Triki M, Carmona $P$ and JiménezColmenero F, Effects of emulsion gels containing bioactive compounds on sensorial, technological, and structural properties of frankfurters. Food Sci Technol Int 22: 132-145 (2016). DOI: 10.1177/1082013215577033.

57 Delgado-Pando G, Cofrades S, Ruiz-Capillas C, Solas MT, Triki M and JiménezColmenero F, Low-fat frankfurters formulated with a healthier lipid combination as functional ingredient: Microstructure, lipid oxidation, nitrite content, microbiological changes and biogenic amine formation. Meat Sci 89: 65-71 (2011). DOI: http://dx.doi.org/10.1016/j.meatsci.2011.03.022.

58 Bertram HC, Straadt IK, Jensen JA and Aaslyng MD, Relationship between water mobility and distribution and sensory attributes in pork slaughtered at an age between 90 and 180 days. Meat Sci 77: 190-195 (2007). DOI: https://doi.org/10.1016/j.meatsci.2007.03.006.

59 Han M, Clausen MP, Christensen M, Vossen E, Van Hecke T and Bertram HC, Enhancing the health potential of processed meat: the effect of chitosan or carboxymethyl cellulose enrichment on inherent microstructure, water mobility and oxidation in a meat-based food matrix. Food Funct 9: 4017-4027 (2018) 2018/07/07. DOI: $10.1039 / \mathrm{c} 8 f 000835 \mathrm{c}$.

60 García ABG, Rodríguez MIC, de Ávila Hidalgo MDR and Bertram HC, Water mobility and distribution during dry-fermented sausages "Spanish type" manufacturing and its relationship with physicochemical and textural properties: a low-field NMR study. Eur Food Res Technol 243: 455-466 (2017). DOI: 10.1007/s00217-016-2759-0.

61 Rodrigues I, Gonçalves LA, Carvalho FAL, Pires M, Jp Rocha Y, Barros JC et al., Understanding salt reduction in fat-reduced hot dog sausages: Network structure, emulsion stability and consumer acceptance. Food Sci Technol Int 26: 123-131 (2019). DOI: $10.1177 / 1082013219872677$.

62 Hou JJ, Guo J, Wang JM and Yang XQ, Effect of interfacial composition and crumbliness on aroma release in soy protein/sugar beet pectin mixed emulsion gels. $J$ Sci Food Agric 96: 4449-4456 (2016). DOI: doi:10.1002/jsfa.7656.

63 Mao L, Miao S, Yuan F and Gao Y, Study on the textural and volatile characteristics of emulsion filled protein gels as influenced by different fat substitutes. Food Res Int 103: 1-7 (2018). DOI: https://doi.org/10.1016/j.foodres.2017.10.024. 
Figure 1. Emulsion stability (\% exudated liquid) a at day 0 and juiciness evaluation (\%) during chilled storage ( sday 0 aday 15 口day 30 aday 45 iday 60 ) of Bologna sausages. Equal lower case letters for the same color are not statistically different $(p>0.05)$. NF-normal fat, RF-reduced fat, PF-pork back fat, EG- emulsion gel, NS-normal salt, RS-reduced salt. Bars show standard error

Figure 2. Effect of fat and salt reduction on microstructural properties in Bologna sausage with emulsion gel.NF-normal fat, RF-reduced fat, PF-pork back fat, EG- emulsion gel, NS-normal salt, RS-reduced salt

Figure 3. TDNMR - a) The TDNMR curve for the Bologna sausages samples exhibited a LogNormal distribution deconvolution in two water populations. b) $\mathrm{T}_{2}$ center relaxation time and c) relative area of the Bologna sausages samples in distinct shelf life $(0,15,30,45$, and 60 days)

Figure 4. Sensory evaluation of Bologna sausages with emulsion gels. (a) Consumer test, (b) Representation of the samples and attributes in the first two dimensions of the correspondence analysis (CA) of the Bologna-sausages samples using CATA questions, (c) Correlation between sensory attributes and overall liking in the first two dimensions of the CA.NF-normal fat, RFreduced fat, PF-pork back fat, EG- emulsion gel, NS-normal salt, RS-reduced salt 


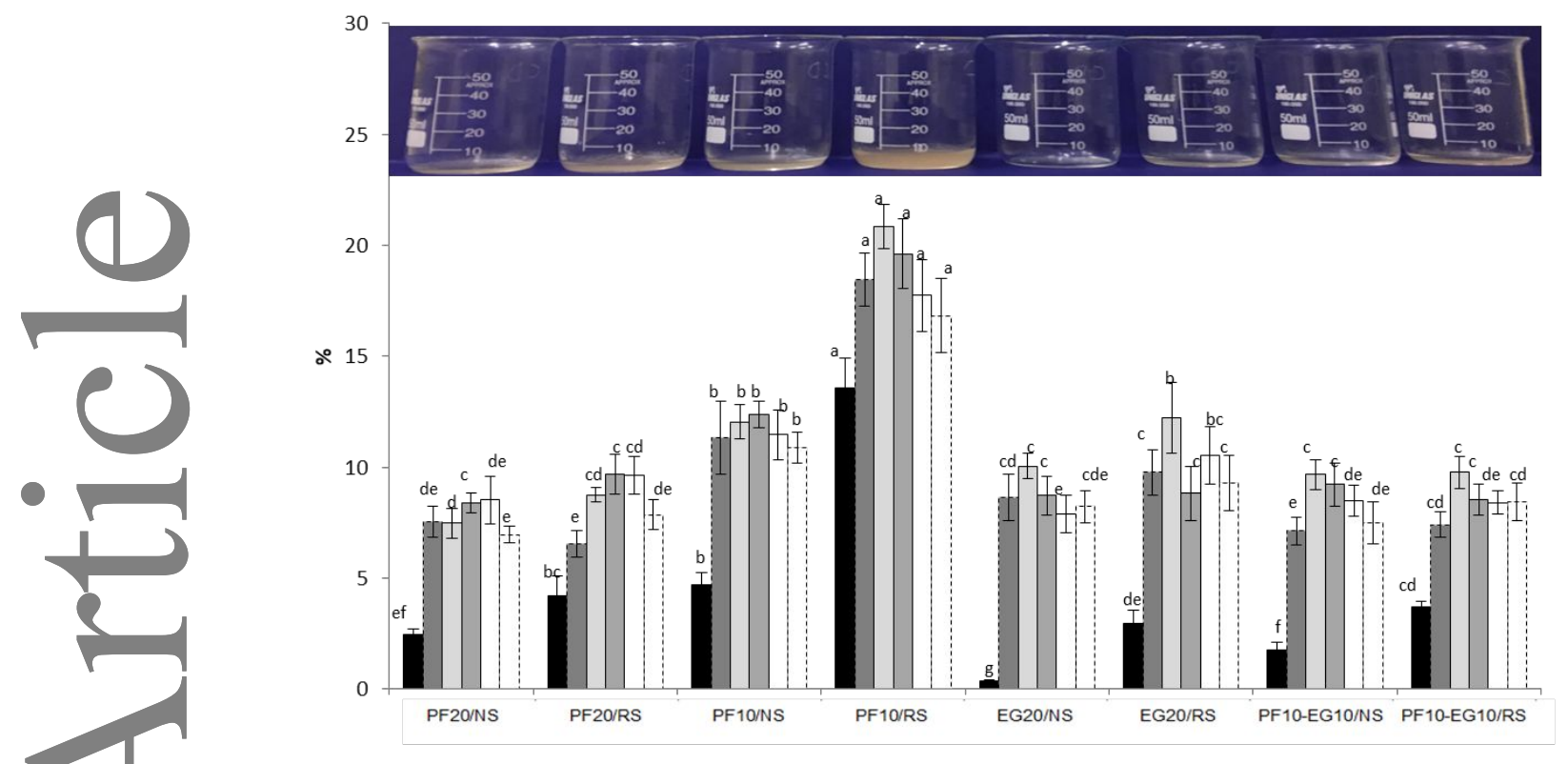

Figure 1.
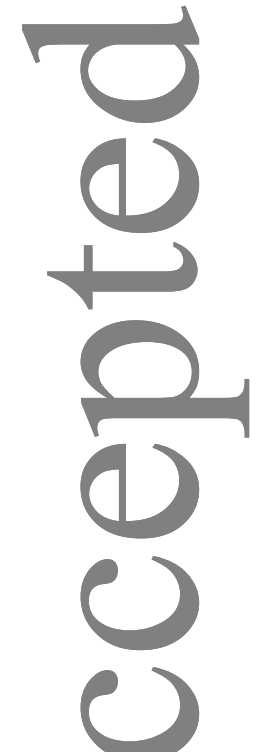

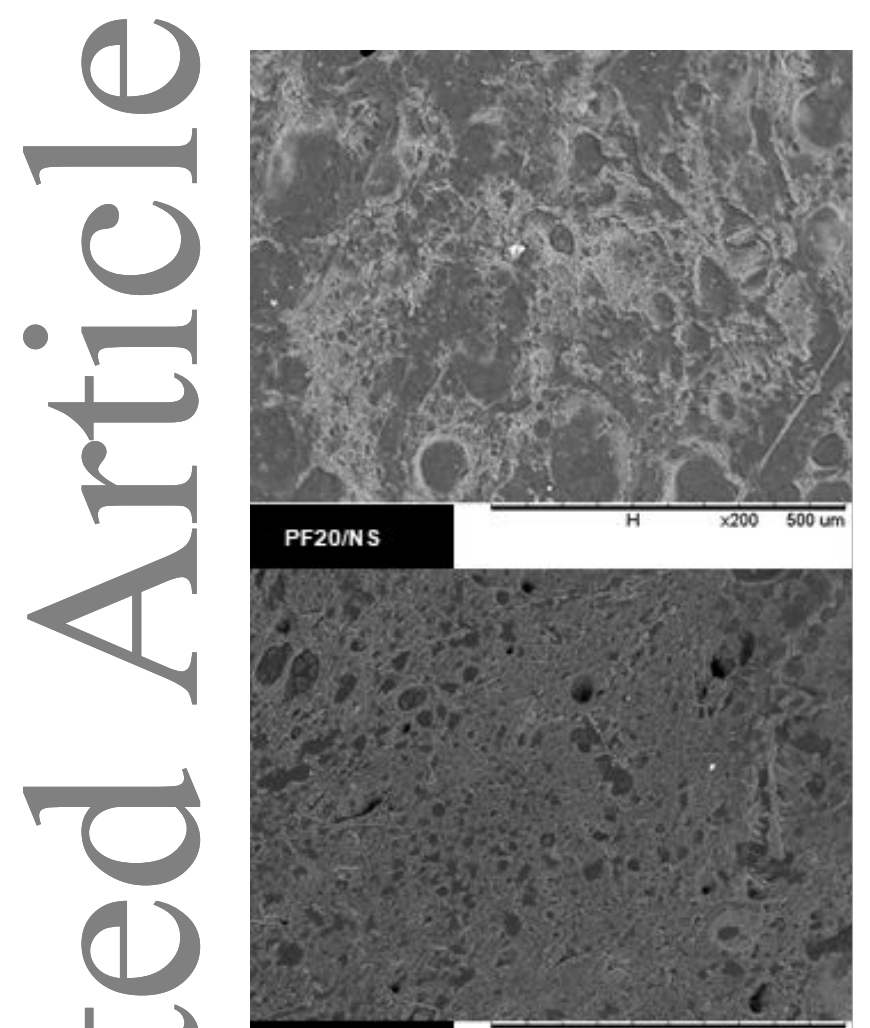

10

$\longrightarrow$

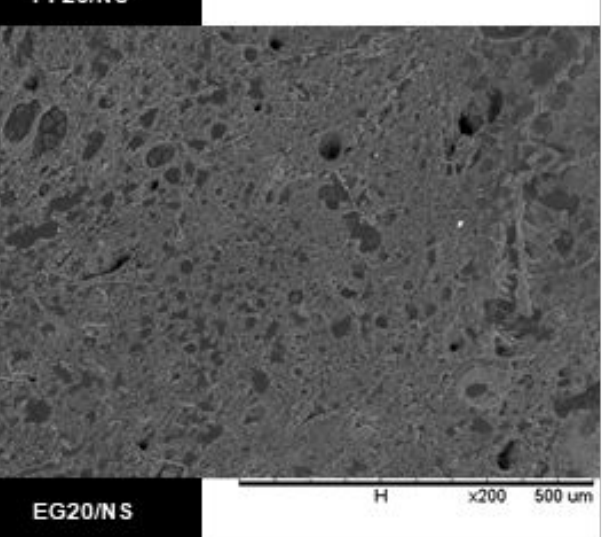

Figure 2.
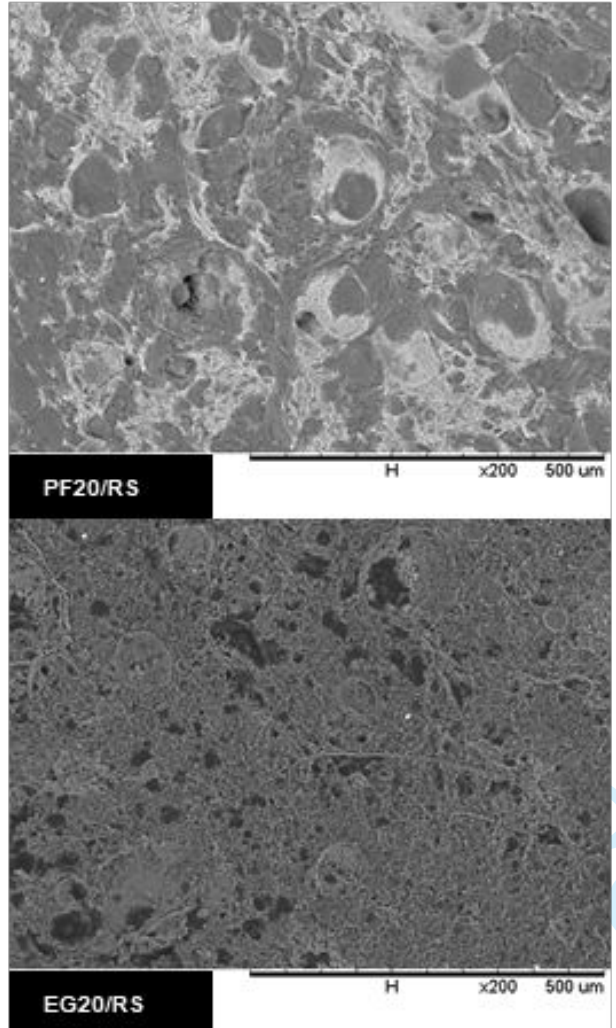

EG20/RS
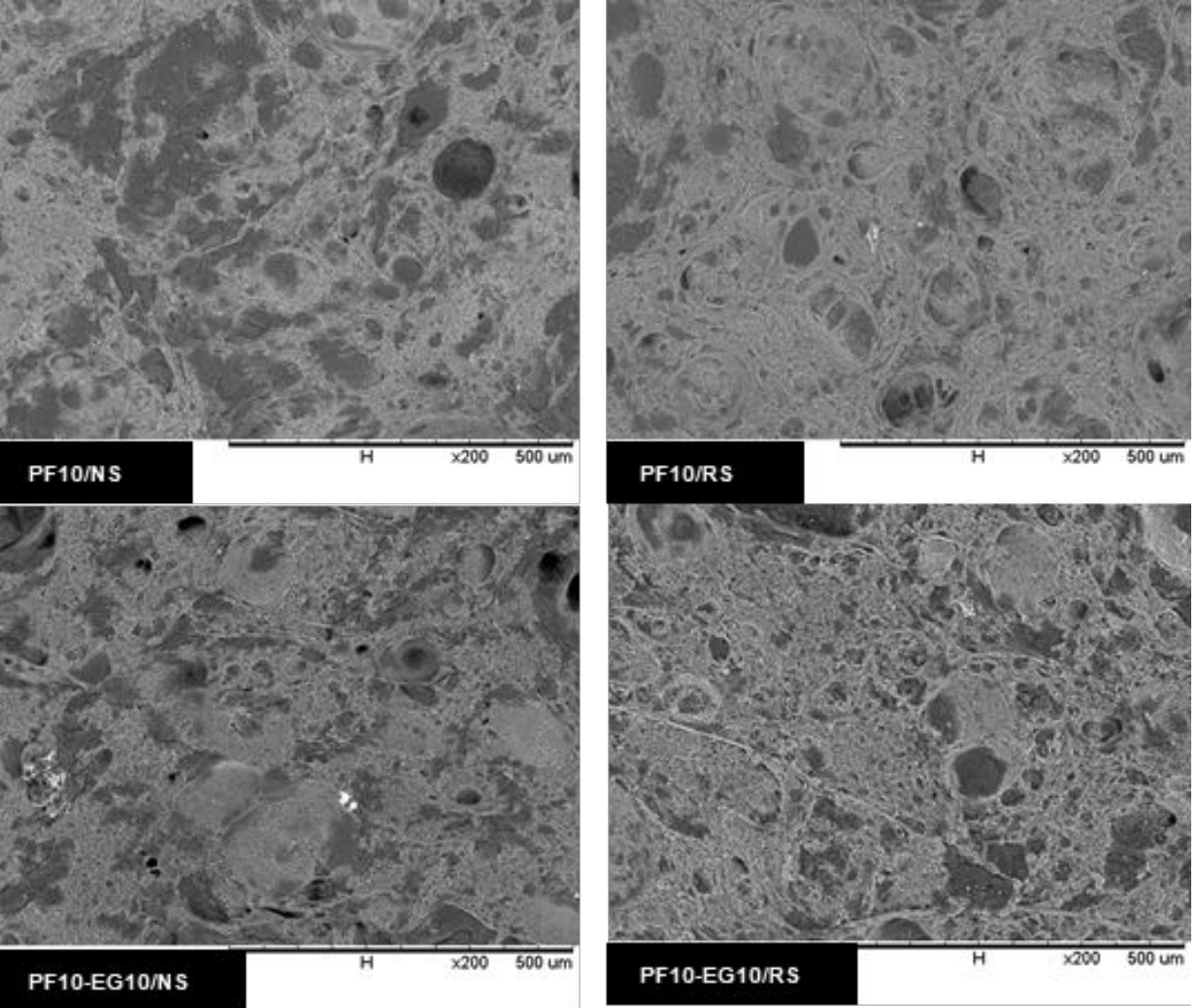

()

(P)

( )

4 
a)

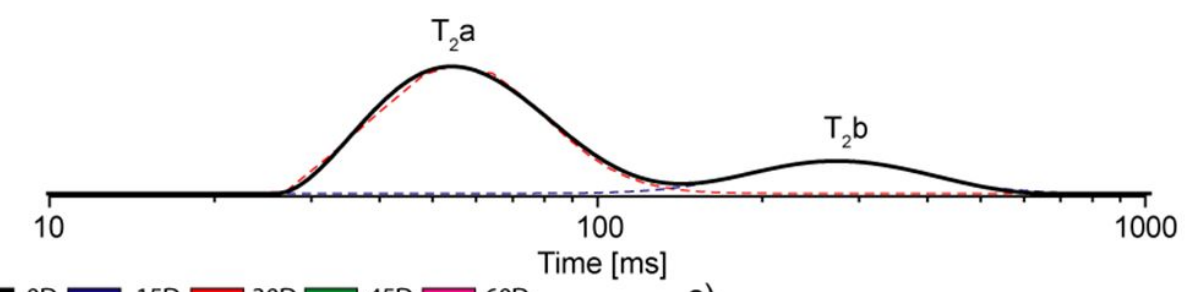

()

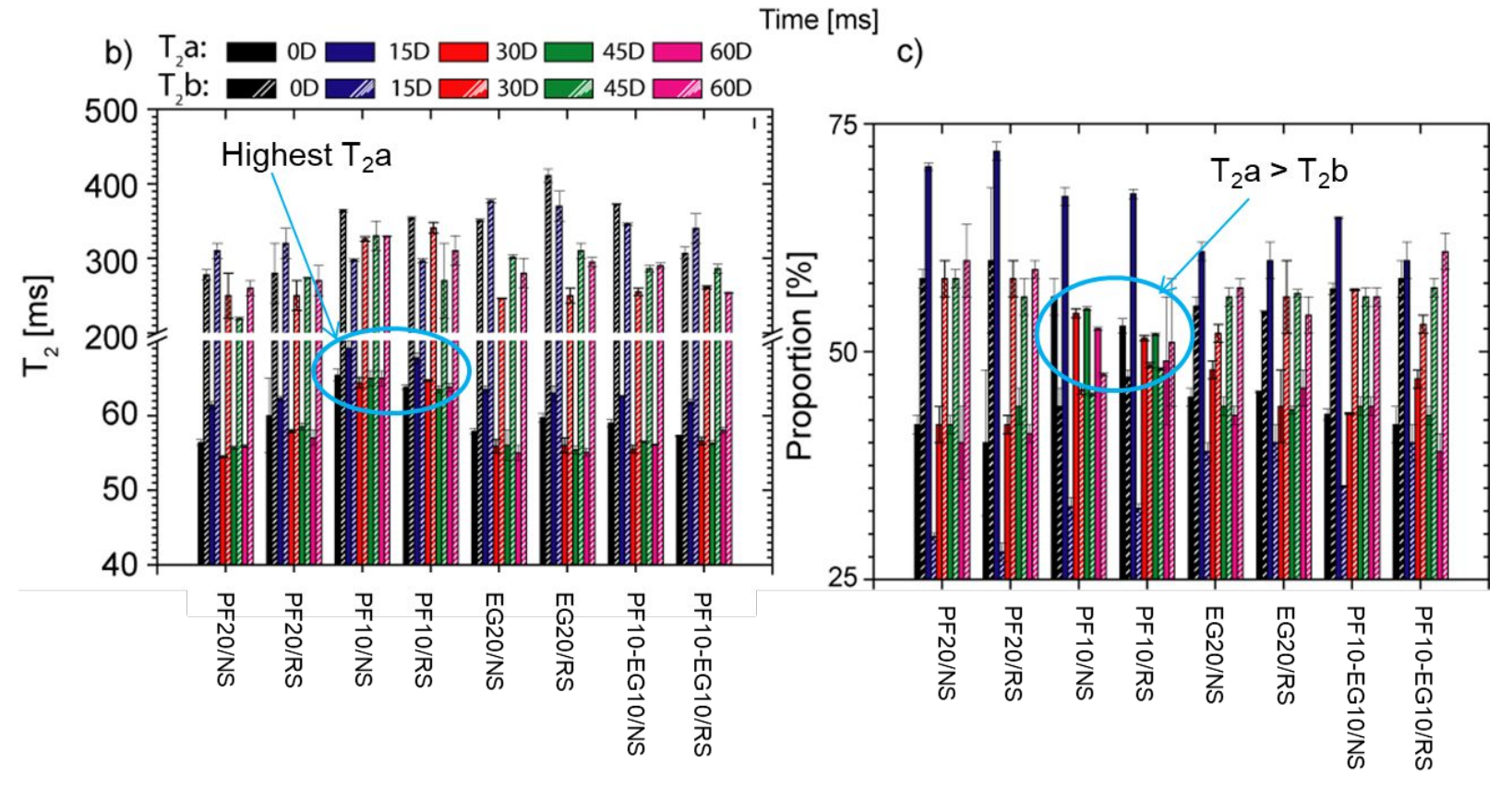

Figure 3. 


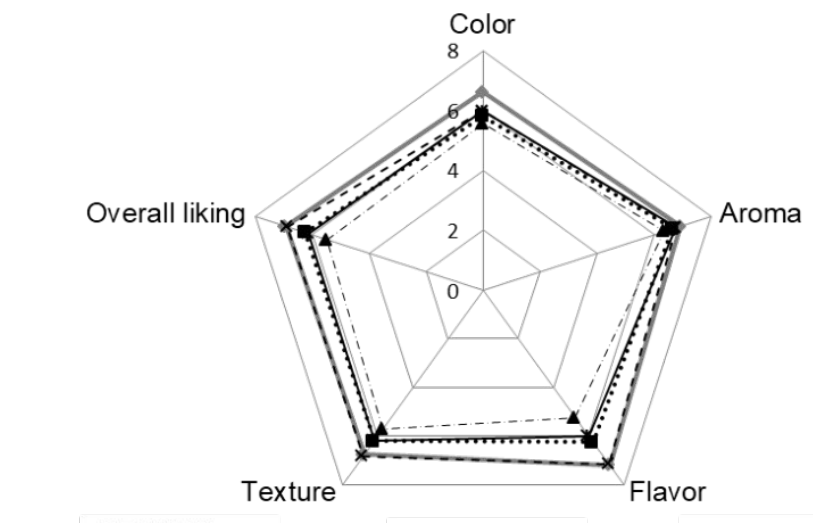

\section{$\rightarrow$ PF20/NS}

- - - PF10-EG10/NS
EG20/RS PF10-EG10/RS

(a)

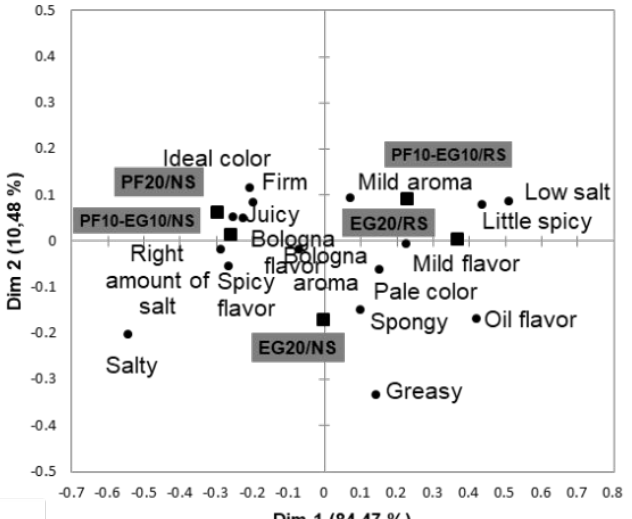

$\operatorname{Dim} 1(84,47 \%)$

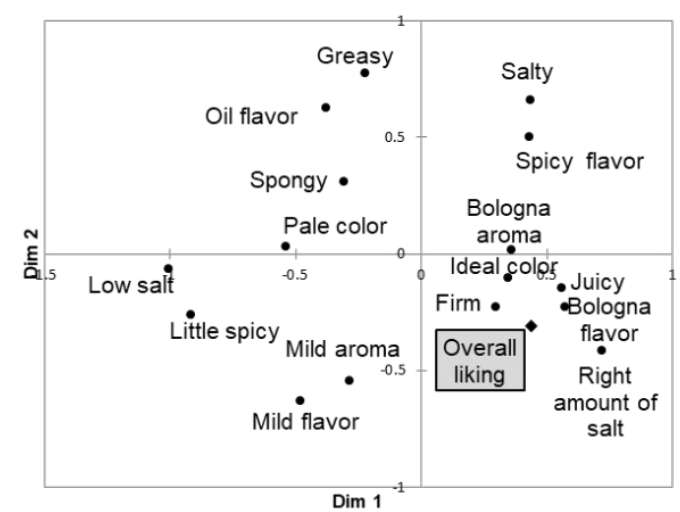

(c)

Figure 4. 
Table 1. Description of treatments $(\%, w / w)$ of Bologna sausage elaborated with mechanically deboned chicken meat (MDCM) and inulin-based emulsion gel

\begin{tabular}{ccccccc}
\hline Treatments & MDCM & Pork meat & PF & EG & NaCl & Water \\
\hline PF20/NS & 50 & 20 & 20 & 0 & 2 & 7.2 \\
PF20/RS & 50 & 20 & 20 & 0 & 1 & 8.2 \\
PF10/NS & 50 & 20 & 10 & 0 & 2 & 17.2 \\
PF10/RS & 50 & 20 & 10 & 0 & 1 & 18.2 \\
EG20/NS & 50 & 20 & 0 & 20 & 2 & 7.2 \\
EG20/RS & 50 & 20 & 0 & 20 & 1 & 8.2 \\
PF10-EG10/NS & 50 & 20 & 10 & 10 & 2 & 7.2 \\
PF10-EG10/RS & 50 & 20 & 10 & 10 & 1 & 8.2 \\
\hline
\end{tabular}

Note: PF- pork back fat, EG- emulsion gel, NS- normal salt, RS- reduced salt, MDCM- Mechanically deboned chicken meat. Additives: $0.25 \mathrm{~g} / 100 \mathrm{~g}$ sodium tripolyphosphate; $0.05 \mathrm{~g} / 100 \mathrm{~g}$ sodium ascorbate; $0.52 \mathrm{~g} / 100 \mathrm{~g}$ seasoning and $150 \mathrm{ppm}$ sodium nitrite.

Table 2. Chemical composition $\left(\mathrm{g} / \mathrm{kg}^{-1}\right)$, sodium content $\left(\mathrm{g} / \mathrm{kg}^{-1}\right)$, energy content (Kcal), and estimated total dietary fiber $\left(\mathrm{g} / \mathrm{kg}^{-1}\right)$ of Bologna sausages

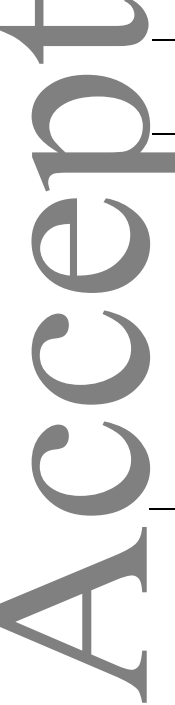

\begin{tabular}{cccccccc} 
Moisture & Fat & Protein & Ash & Carbohydrates & Sodium & $\begin{array}{c}\text { Energy } \\
\text { content }\end{array}$ & TDF $^{* *}$ \\
\hline $593.4 \pm 2.8^{\mathrm{g}}$ & $248.5 \pm 6.6^{\mathrm{a}}$ & $126.9 \pm 2.7^{\mathrm{abc}}$ & $30.9 \pm 0.6^{\mathrm{ab}}$ & $0.00 \pm 0.00^{\mathrm{d}}$ & $8.06 \pm 0.10^{\mathrm{b}}$ & $275 \pm 4^{\mathrm{a}}$ & - \\
$592.4 \pm 3.0^{\mathrm{g}}$ & $249.9 \pm 3.1^{\mathrm{a}}$ & $132.4 \pm 3.5^{\mathrm{a}}$ & $21.4 \pm 0.6^{\mathrm{cd}}$ & $3.7 \pm 0.32^{\mathrm{cd}}$ & $5.05 \pm 0.26^{\mathrm{d}}$ & $280 \pm 2^{\mathrm{a}}$ & - \\
$675.6 \pm 3.7^{\mathrm{b}}$ & $163.3 \pm 5.6^{\mathrm{e}}$ & $120.5 \pm 3.3^{\mathrm{de}}$ & $30.5 \pm 0.3^{\mathrm{b}}$ & $11.5 \pm 0.81^{\mathrm{bcd}}$ & $8.63 \pm 0.18^{\mathrm{a}}$ & $200 \pm 3^{\mathrm{d}}$ & - \\
$683.0 \pm 7.7^{\mathrm{a}}$ & $163.8 \pm 4.4^{\mathrm{e}}$ & $124.2 \pm 1.5^{\mathrm{cd}}$ & $20.5 \pm 0.2^{\mathrm{d}}$ & $10.5 \pm 0.57^{\mathrm{bcd}}$ & $4.72 \pm 0.06^{\mathrm{e}}$ & $201 \pm 4^{\mathrm{d}}$ & - \\
$619.0 \pm 3.0^{\mathrm{d}}$ & $201.8 \pm 5.6^{\mathrm{c}}$ & $118.6 \pm 6.5^{\mathrm{e}}$ & $30.7 \pm 1.3^{\mathrm{ab}}$ & $35.1 \pm 9.1^{\mathrm{a}}$ & $7.58 \pm 0.26^{\mathrm{c}}$ & $235 \pm 3^{\mathrm{c}}$ & 29.7 \\
$628.9 \pm 2.9^{\mathrm{c}}$ & $190.4 \pm 6.3^{\mathrm{d}}$ & $124.9 \pm 3.7^{\mathrm{cd}}$ & $21.6 \pm 0.3^{\mathrm{c}}$ & $38.0 \pm 6.8^{\mathrm{a}}$ & $4.91 \pm 0.07^{\mathrm{de}}$ & $229 \pm 4^{\mathrm{c}}$ & 29.7 \\
$604.0 \pm 1.5^{\mathrm{f}}$ & $220.0 \pm 5.8^{\mathrm{b}}$ & $131.3 \pm 4.1^{\mathrm{ab}}$ & $31.5 \pm 0.2^{\mathrm{a}}$ & $17.7 \pm 6.4^{\mathrm{bc}}$ & $7.69 \pm 0.17^{\mathrm{c}}$ & $253 \pm 3^{\mathrm{b}}$ & 14.9 \\
$612.0 \pm 6.4^{\mathrm{e}}$ & $218.5 \pm 5.2^{\mathrm{b}}$ & $126.0 \pm 1.1^{\mathrm{bc}}$ & $22.1 \pm 0.6^{\mathrm{c}}$ & $20.4 \pm 4.8^{\mathrm{b}}$ & $4.91 \pm 0.19^{\text {de }}$ & $253 \pm 5^{\mathrm{b}}$ & 14.9 \\
\hline
\end{tabular}

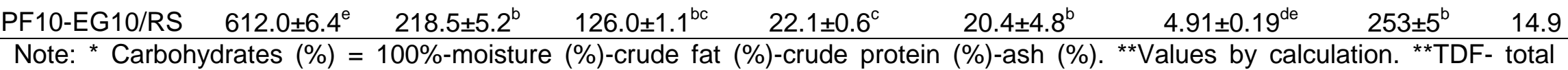
dietary fiber. Estimated from Inulin fiber content (90\%). Equal letters in the same column are not statistically different (p>0.05). PFpork back fat, EG-emulsion gel, NS-normal salt, RS-reduced salt. 
Table 3. Fatty acid composition of Bologna sausage ( $\mathrm{g} / \mathrm{kg}^{-1}$ product)

\begin{tabular}{|c|c|c|c|c|}
\hline Fatty acid & $\begin{array}{l}\text { PF20/NS and } \\
\text { PF20/RS }\end{array}$ & $\begin{array}{l}\text { PF10/NS and } \\
\text { PF10/RS }\end{array}$ & $\begin{array}{c}\text { EG20/NS and } \\
\text { EG20/RS }\end{array}$ & $\begin{array}{l}\text { PF10-EG10/NS and } \\
\text { PF10-EG10/RS }\end{array}$ \\
\hline C8:0 caprylic & $0.12 \pm 0.00^{N S^{*}}$ & $0.12 \pm 0.00^{\mathrm{NS} S^{*}}$ & $0.12 \pm 0.00^{\mathrm{NS}}$ & $0.12 \pm 0.00^{\mathrm{NS}^{*}}$ \\
\hline C10:0 capric & $0.16 \pm 0.00^{a}$ & $0.10 \pm 0.00^{c}$ & $0.06 \pm 0.00^{d}$ & $0.11 \pm 0.00^{b}$ \\
\hline C12:0 lauric & $0.35 \pm 0.00^{a}$ & $0.22 \pm 0.00^{c}$ & $0.14 \pm 0.01^{d}$ & $0.24 \pm 0.00^{b}$ \\
\hline C14:0 myristic & $3.00 \pm 0.01^{\mathrm{a}}$ & $1.82 \pm 0.00^{c}$ & $0.99 \pm 0.01^{d}$ & $1.95 \pm 0.01^{b}$ \\
\hline C15:0 pentadecylic & $0.21 \pm 0.00^{a}$ & $0.16 \pm 0.00^{c}$ & $0.16 \pm 0.00^{c}$ & $0.18 \pm 0.00^{b}$ \\
\hline C16:0 palmitic & $59.81 \pm 0.20^{a}$ & $39.64 \pm 0.07^{c}$ & $34.80 \pm 0.70^{d}$ & $46.52 \pm 0.19^{b}$ \\
\hline C17:0 margaric & $0.67 \pm 0.02^{\mathrm{a}}$ & $0.43 \pm 0.02^{c}$ & $0.34 \pm 0.01^{d}$ & $0.49 \pm 0.02^{b}$ \\
\hline C18:0 stearic & $28.08 \pm 0.15^{a}$ & $16.88 \pm 0.08^{c}$ & $11.48 \pm 0.22^{d}$ & $19.35 \pm 0.13^{b}$ \\
\hline C20:0 arachidic & $0.57 \pm 0.01^{a}$ & $0.35 \pm 0.01^{b}$ & $0.57 \pm 0.03^{a}$ & $0.56 \pm 0.01^{a}$ \\
\hline C22:0 behenic & $0.22 \pm 0.01^{c}$ & $0.17 \pm 0.00^{d}$ & $0.64 \pm 0.03^{a}$ & $0.43 \pm 0.00^{b}$ \\
\hline$\Sigma$ SFA & $93.20 \pm 0.34^{a}$ & $59.91 \pm 0.11^{c}$ & $49.30 \pm 0.98^{d}$ & $69.96 \pm 0.32^{b}$ \\
\hline C16:1 palmitolenic & $7.57 \pm 0.03^{a}$ & $5.50 \pm 0.03^{c}$ & $3.99 \pm 0.03^{d}$ & $5.70 \pm 0.03^{b}$ \\
\hline C17:1 cis-10-heptadecenoic & $0.43 \pm 0.01^{a}$ & $0.26 \pm 0.00^{c}$ & $0.18 \pm 0.00^{d}$ & $0.30 \pm 0.00^{b}$ \\
\hline C18:1n-9 oleic & $101.5 \pm 0.36^{a}$ & $65.24 \pm 0.13^{c}$ & $59.54 \pm 1.43^{d}$ & $79.12 \pm 0.35^{\mathrm{b}}$ \\
\hline C20:1 eicosenoic & $1.81 \pm 0.08^{\mathrm{a}}$ & $0.99 \pm 0.04^{c}$ & $0.56 \pm 0.02^{d}$ & $1.15 \pm 0.05^{\mathrm{b}}$ \\
\hline$\Sigma$ MUFA & $111.3 \pm 0.4^{a}$ & $72.00 \pm 0.15^{c}$ & $64.27 \pm 1.46^{d}$ & $86.27 \pm 0.39^{b}$ \\
\hline C18:1 trans & $0.62 \pm 0.22^{\mathrm{a}}$ & $0.38 \pm 0.10^{b}$ & $0.20 \pm 0.00^{b}$ & $0.40 \pm 0.11^{\mathrm{b}}$ \\
\hline C18:2 trans & $0.10 \pm 0.00^{c}$ & $0.04 \pm 0.00^{d}$ & $0.28 \pm 0.02^{a}$ & $0.19 \pm 0.00^{b}$ \\
\hline C18:3 trans & $0.01 \pm 0.00^{c}$ & $0.01 \pm 0.00^{c}$ & $1.03 \pm 0.06^{a}$ & $0.52 \pm 0.00^{b}$ \\
\hline C18:2n-6.linoleic & $40.60 \pm 0.11^{c}$ & $28.72 \pm 0.04^{d}$ & $72.99 \pm 3.34^{a}$ & $56.26 \pm 0.11^{\mathrm{b}}$ \\
\hline C18:3n-3.linolenic & $2.36 \pm 0.01^{c}$ & $1.78 \pm 0.00^{\mathrm{d}}$ & $7.38 \pm 0.38^{a}$ & $4.84 \pm 0.01^{\mathrm{b}}$ \\
\hline$\Sigma$ PUFA & $42.97 \pm 0.12^{c}$ & $30.50 \pm 0.04^{d}$ & $80.37 \pm 3.72^{a}$ & $61.10 \pm 0.12^{b}$ \\
\hline PUFA/SFA & $0.46 \pm 0.00^{d}$ & $0.51 \pm 0.00^{c}$ & $1.63 \pm 0.04^{a}$ & $0.87 \pm 0.00^{\mathrm{b}}$ \\
\hline$n-6 / n-3$ & $17.16 \pm 0.05^{a}$ & $16.13 \pm 0.04^{b}$ & $9.89 \pm 0.05^{d}$ & $11.62 \pm 0.01^{c}$ \\
\hline Thrombogenic index (TI) & $1.09 \pm 0.00^{a}$ & $1.04 \pm 0.00^{b}$ & $0.51 \pm 0.01^{d}$ & $0.78 \pm 0.00^{c}$ \\
\hline Atherogenic index (Al) & $0.47 \pm 0.00^{a}$ & $0.46 \pm 0.00^{b}$ & $0.27 \pm 0.00^{d}$ & $0.37 \pm 0.00^{c}$ \\
\hline
\end{tabular}

Equal lower case letters in the same column are not statistically different $(p>0.05)$. Means \pm standard deviation. NS ${ }^{*}$, not significant. NS- normal salt; RS- reduced salt; EG- emulsion gel 
Table 4. $\mathrm{pH}, \mathrm{a}_{\mathrm{w}}$, TBARS values and color parameters of reformulated Bologna sausages during chilled storage

\begin{tabular}{|c|c|c|c|c|c|c|c|}
\hline & & & & Days & & & \\
\hline & Samples & 0 & 15 & 30 & 45 & 60 & SEM \\
\hline & PF20/NS & $6.28^{\mathrm{CB}}$ & $6.26^{\mathrm{deBC}}$ & $6.25^{\mathrm{Cc}}$ & $6.19^{\mathrm{dD}}$ & $6.43^{\mathrm{abA}}$ & 0.01 \\
\hline & PF20/RS & $6.35^{\mathrm{aB}}$ & $6.40^{\mathrm{aB}}$ & $6.35^{\mathrm{aB}}$ & $6.29^{\mathrm{aC}}$ & $6.46^{\mathrm{Aa}}$ & 0.01 \\
\hline & PF10/NS & $6.29^{\mathrm{bc} A \mathrm{~B}}$ & $6.31^{\mathrm{cdAB}}$ & $6.31^{\mathrm{bAB}}$ & $6.23^{\mathrm{cB}}$ & $6.34^{\mathrm{bA}}$ & 0.01 \\
\hline & PF10/RS & $6.35^{\mathrm{aB}}$ & $6.37^{\mathrm{abAB}}$ & $6.38^{\mathrm{aA}}$ & $6.28^{\mathrm{abc}}$ & $6.15^{\mathrm{cdD}}$ & 0.01 \\
\hline $\mathrm{pH}$ & EG20/NS & $6.23^{\mathrm{dB}}$ & $6.26^{\mathrm{deA}}$ & $6.26^{\mathrm{cA}}$ & $6.18^{\mathrm{dC}}$ & $6.10^{\mathrm{dD}}$ & 0.01 \\
\hline & EG20/RS & $6.30^{\mathrm{bc}}$ & $6.32^{\mathrm{bcB}}$ & $6.35^{\mathrm{aA}}$ & $6.26^{\mathrm{bD}}$ & $6.20^{\mathrm{cdE}}$ & 0.01 \\
\hline & PF10-EG10/NS & $6.25^{\mathrm{dB}}$ & $6.25^{\mathrm{eB}}$ & $6.28^{\mathrm{CA}}$ & $6.20^{\mathrm{dC}}$ & $6.13^{\mathrm{cdD}}$ & 0.01 \\
\hline & PF10-EG10/RS & $6.31^{\mathrm{bB}}$ & $6.34^{\mathrm{bcA}}$ & $6.36^{\mathrm{aA}}$ & $6.29^{\mathrm{aB}}$ & $6.23^{\mathrm{cC}}$ & 0.01 \\
\hline & SEM & 0.00 & 0.01 & 0.00 & 0.00 & 0.02 & \\
\hline & PF20/NS & $0.973^{\mathrm{cNS}}{ }^{*}$ & $0.973^{\mathrm{dNS}}$ & $0.973^{\mathrm{cNS}}{ }^{*}$ & $0.972^{\mathrm{dNS}}{ }^{*}$ & $0.974^{\mathrm{dNS}}{ }^{*}$ & $<0.0001$ \\
\hline & PF20/RS & $0.977^{\mathrm{bc}}$ & $0.981^{\mathrm{bB}}$ & $0.979^{\mathrm{bB}}$ & $0.984^{\mathrm{abA}}$ & $0.980^{\mathrm{bB}}$ & $<0.0001$ \\
\hline & PF10/NS & $0.973^{\mathrm{cC}}$ & $0.976^{\mathrm{cBC}}$ & $0.975^{\mathrm{CBC}}$ & $0.978^{\mathrm{CAB}}$ & $0.980^{\mathrm{bcA}}$ & $<0.0001$ \\
\hline & PF10/RS & $0.982^{\mathrm{aB}}$ & $0.983^{\mathrm{aAB}}$ & $0.982^{\mathrm{aAB}}$ & $0.984^{\mathrm{aAB}}$ & $0.984^{\mathrm{aA}}$ & $<0.0001$ \\
\hline$a_{w}$ & EG20/NS & $0.970^{\mathrm{dD}}$ & $0.972^{d C}$ & $0.974^{\mathrm{cBC}}$ & $0.974^{\mathrm{dB}}$ & $0.976^{\mathrm{cdA}}$ & $<0.0001$ \\
\hline & EG20/RS & $0.979^{\mathrm{abc}}$ & $0.981^{\mathrm{bB}}$ & $0.981^{\mathrm{abB}}$ & $0.981^{\mathrm{bB}}$ & $0.985^{\mathrm{aA}}$ & $<0.0001$ \\
\hline & PF10-EG10/NS & $0.971^{\mathrm{cdC}}$ & $0.973^{\mathrm{dB}}$ & $0.973^{\mathrm{cBC}}$ & $0.973^{\mathrm{dB}}$ & $0.976^{\mathrm{cdA}}$ & $<0.0001$ \\
\hline & PF10-EG10/RS & $0.981^{\mathrm{aB}}$ & $0.982^{\mathrm{abB}}$ & $0.980^{\mathrm{abB}}$ & $0.982^{\mathrm{abB}}$ & $0.985^{\mathrm{aA}}$ & $<0.0001$ \\
\hline & SEM & 0.000 & 0.000 & 0.000 & 0.001 & 0.001 & \\
\hline & PF20/NS & $0.10^{\mathrm{dB}}$ & $0.12^{\mathrm{CA}}$ & $0.11^{\mathrm{CAB}}$ & $0.08^{\mathrm{cC}}$ & $0.05^{\mathrm{dD}}$ & 0.00 \\
\hline & PF20/RS & $0.10^{\mathrm{dB}}$ & $0.12^{\mathrm{cA}}$ & $0.09^{\mathrm{cB}}$ & $0.04^{\mathrm{CD}}$ & $0.06^{d C}$ & 0.00 \\
\hline & PF10/NS & $0.09^{d A}$ & $0.08^{\mathrm{CAB}}$ & $0.09^{\mathrm{cA}}$ & $0.07^{\mathrm{CB}}$ & $0.04^{d C}$ & 0.00 \\
\hline TBARS & PF10/RS & $0.09^{\mathrm{dB}}$ & $0.10^{\mathrm{cB}}$ & $0.12^{\mathrm{cA}}$ & $0.07^{\mathrm{cC}}$ & $0.07^{\mathrm{dC}}$ & 0.00 \\
\hline (mg MDA) & EG20/NS & $0.78^{\mathrm{bB}}$ & $0.76^{\mathrm{aB}}$ & $0.89^{\mathrm{aA}}$ & $0.46^{\mathrm{aC}}$ & $0.36^{\mathrm{aD}}$ & 0.03 \\
\hline $\mathrm{kg}$ & EG20/RS & $0.84^{\mathrm{aAB}}$ & $0.77^{\mathrm{aB}}$ & $0.85^{\mathrm{aA}}$ & $0.50^{\mathrm{aC}}$ & $0.34^{\mathrm{aD}}$ & 0.03 \\
\hline & PF10-EG10/NS & $0.45^{\mathrm{cB}}$ & $0.43^{\mathrm{bB}}$ & $0.52^{\mathrm{bA}}$ & $0.27^{\mathrm{bC}}$ & $0.20^{\mathrm{cD}}$ & 0.02 \\
\hline & PF10-EG10/RS & $0.47^{\mathrm{CA}}$ & $0.48^{\mathrm{bA}}$ & $0.52^{\mathrm{bA}}$ & $0.28^{\mathrm{bB}}$ & $0.25^{\mathrm{bB}}$ & 0.02 \\
\hline & SEM & 0.04 & 0.03 & 0.04 & 0.02 & 0.02 & \\
\hline & PF20/NS & $63.29^{\mathrm{dNS}^{*}}$ & $63.37^{\mathrm{eNS}^{*}}$ & $63.16^{\mathrm{dNS} S^{*}}$ & $63.75^{\mathrm{dNS}}$ & $63.58^{\mathrm{dNS}}{ }^{*}$ & 0.11 \\
\hline & PF20/RS & $65.25^{\mathrm{cC}}$ & $65.74^{\mathrm{cABC}}$ & $65.91^{\mathrm{CAB}}$ & $66.33^{\mathrm{bA}}$ & $65.62^{\mathrm{bBC}}$ & 0.08 \\
\hline$L^{*}$ & PF10/NS & $63.77^{\mathrm{dNS}^{*}}$ & $63.94^{\text {deNS }}{ }^{*}$ & $63.41^{\mathrm{dNS} S^{*}}$ & $63.49^{\mathrm{dNS}^{*}}$ & $63.57^{\mathrm{dNS}^{*}}$ & 0.09 \\
\hline & PF10/RS & $64.37^{\mathrm{cdAB}}$ & $64.65^{\mathrm{dAB}}$ & $64.09^{\mathrm{dB}}$ & $65.06^{\mathrm{cA}}$ & $64.70^{\mathrm{CAB}}$ & 0.13 \\
\hline & EG20/NS & $66.80^{\mathrm{abAB}}$ & $67.52^{\mathrm{abA}}$ & $67.16^{\mathrm{abAB}}$ & $67.54^{\mathrm{aA}}$ & $66.68^{\mathrm{aB}}$ & 0.10 \\
\hline
\end{tabular}




\begin{tabular}{|c|c|c|c|c|c|c|c|}
\hline & $\begin{array}{c}\text { EG20/RS } \\
\text { PF10-EG10/NS } \\
\text { PF10-EG10/RS }\end{array}$ & $\begin{array}{c}67.80^{\mathrm{aA}} \\
66.95^{\mathrm{abNS}}{ }^{*} \\
66.57^{\mathrm{bNS} *}\end{array}$ & $\begin{array}{c}67.96^{\mathrm{aA}} \\
66.73^{\mathrm{bcNS}}{ }^{*} \\
67.15^{\mathrm{abNS}}\end{array}$ & $\begin{array}{c}67.65^{\mathrm{aAB}} \\
66.23^{\mathrm{bcNS}}{ }^{*} \\
66.60^{\mathrm{abcNS}}\end{array}$ & $\begin{array}{l}67.50^{\mathrm{abAB}} \\
66.55^{\mathrm{abNS}}{ }^{*} \\
67.09^{\mathrm{abNS}}\end{array}$ & $\begin{array}{c}66.64^{\mathrm{aB}} \\
66.38^{\mathrm{abNS}}{ }^{*} \\
66.36^{\mathrm{abNS}}\end{array}$ & $\begin{array}{l}0.18 \\
0.09 \\
0.11\end{array}$ \\
\hline & SEM & 0.20 & 0.21 & 0.21 & 0.20 & 0.16 & \\
\hline \multirow{9}{*}{$a^{*}$} & PF20/NS & $11.27^{\mathrm{a}}$ & $11.21^{\mathrm{a}}$ & $11.39^{a}$ & $11.14^{\mathrm{a}}$ & $11.01^{\mathrm{a}}$ & 0.06 \\
\hline & PF20/RS & $10.49^{\mathrm{bcNS}}{ }^{*}$ & $10.36^{\text {bcdNS* }}$ & $10.46^{\text {bcdNS* }}$ & $10.23^{\mathrm{bNS}}{ }^{*}$ & $10.39^{\mathrm{bcNS}^{*}}$ & 0.03 \\
\hline & PF10/NS & $10.71^{\mathrm{bNS}}{ }^{*}$ & $10.69^{\mathrm{abNS}}{ }^{*}$ & $10.84^{\mathrm{bNS}}{ }^{\star}$ & $10.81^{\mathrm{aNS}}{ }^{*}$ & $10.68^{\mathrm{abNS}}{ }^{*}$ & 0.06 \\
\hline & PF10/RS & $10.65^{\mathrm{bcA}}$ & $10.63^{\mathrm{bcA}}$ & $10.78^{\mathrm{bcA}}$ & $10.32^{\mathrm{bAB}}$ & $10.10^{\mathrm{cB}}$ & 0.07 \\
\hline & EG20/NS & $9.94^{\mathrm{dNS}^{*}}$ & $9.96^{\mathrm{deNS}^{*}}$ & $10.13^{\mathrm{deNS} S^{*}}$ & $10.07^{\mathrm{bNS}}{ }^{*}$ & $10.09^{\mathrm{cNS}^{*}}$ & 0.03 \\
\hline & EG20/RS & $9.88^{\mathrm{dNS}^{*}}$ & $9.75^{\mathrm{eNS}^{*}}$ & $9.84^{\mathrm{eNS}^{*}}$ & $10.13^{\mathrm{bNS}}$ & $10.03^{\mathrm{cNS}}{ }^{*}$ & 0.08 \\
\hline & PF10-EG10/NS & $9.95^{\mathrm{dB}}$ & $10.10^{\mathrm{cde} A B}$ & $10.31^{d A}$ & $9.99^{\mathrm{bAB}}$ & $9.98^{\mathrm{CAB}}$ & 0.04 \\
\hline & PF10-EG10/RS & $10.19^{\mathrm{cdNS}}$ & $9.99^{\text {deNS* }}$ & $10.34^{\mathrm{cdNS}{ }^{*}}$ & $10.09^{\mathrm{bNS}}{ }^{*}$ & $10.29^{\text {bcNS* }}$ & 0.05 \\
\hline & SEM & 0.06 & 0.07 & 0.06 & 0.06 & 0.06 & \\
\hline \multirow{9}{*}{$b^{*}$} & PF20/NS & $13.32^{\mathrm{abNS}}$ & $13.27^{\mathrm{abNS}}$ & $13.67^{\mathrm{abcNS}^{*}}$ & $13.46^{\mathrm{bcNS}^{*}}$ & $13.44^{\mathrm{abNS}}$ & 0.05 \\
\hline & PF20/RS & $13.20^{\mathrm{abcBC}}$ & $13.31^{\mathrm{abABC}}$ & $13.48^{\mathrm{bcd} A}$ & $13.07^{\mathrm{dC}}$ & $13.40^{\mathrm{abc} A B}$ & 0.04 \\
\hline & PF10/NS & $12.78^{\mathrm{dB}}$ & $12.93^{\mathrm{abAB}}$ & $13.23^{\mathrm{dA}}$ & $13.21^{\mathrm{cdA}}$ & $12.95^{\mathrm{bcAB}}$ & 0.06 \\
\hline & PF10/RS & $12.83^{\mathrm{cdB}}$ & $12.81^{\mathrm{bB}}$ & $13.35^{\mathrm{cdA}}$ & $13.13^{\mathrm{d} A \mathrm{~B}}$ & $12.86^{\mathrm{cB}}$ & 0.06 \\
\hline & EG20/NS & $13.53^{\mathrm{aBC}}$ & $13.35^{\mathrm{ac}}$ & $13.92^{\mathrm{aA}}$ & $13.70^{\mathrm{abAB}}$ & $13.81^{\mathrm{aA}}$ & 0.04 \\
\hline & EG20/RS & $13.48^{\mathrm{aNS}^{*}}$ & $13.41^{\mathrm{aNS} S^{*}}$ & $13.78^{\mathrm{abNS}}$ & $13.77^{\mathrm{aNS}^{*}}$ & $13.75^{\mathrm{aNS}^{*}}$ & 0.06 \\
\hline & PF10-EG10/NS & $12.99^{\mathrm{bcdc}}$ & $13.26^{\mathrm{abBC}}$ & $13.88^{\mathrm{aA}}$ & $13.61^{\mathrm{abA}}$ & $13.54^{\mathrm{aAB}}$ & 0.07 \\
\hline & PF10-EG10/RS & $13.43^{\mathrm{aAB}}$ & $13.24^{\mathrm{abB}}$ & $13.75^{\mathrm{abA}}$ & $13.66^{\mathrm{abAB}}$ & $13.84^{\mathrm{Aa}}$ & 0.06 \\
\hline & SEM & 0.05 & 0.05 & 0.04 & 0.04 & 0.06 & \\
\hline \multirow{8}{*}{$\Delta \mathrm{E}$} & PF20/NS & - & - & - & - & - & - \\
\hline & PF20/RS & 2.11 & 2.61 & 2.75 & 3.22 & 2.49 & - \\
\hline & PF10/NS & 0.91 & 0.95 & 0.46 & 0.51 & 0.75 & - \\
\hline & PF10/RS & 1.34 & 1.59 & 0.94 & 2.02 & 1.89 & - \\
\hline & EG20/NS & 3.76 & 4.43 & 4.08 & 4.43 & 3.62 & - \\
\hline & EG20/RS & 4.72 & 4.91 & 4.61 & 4.38 & 3.60 & - \\
\hline & PF10-EG10/NS & 3.90 & 3.63 & 3.14 & 3.51 & 3.36 & - \\
\hline & PF10-EG10/RS & 3.45 & 4.07 & 3.46 & 3.99 & 3.26 & - \\
\hline
\end{tabular}

Equal lower case letters in the same column are not statistically different $(p>0.05)$. Equal capital letters in the same row for the same parameter are not statistically different $(p>0.05)$. Note: NS*, not significant; PF- pork back fat; NS- normal salt; RS- reduced salt; EG- emulsion gel 
Table 5. Texture Profile Analysis (TPA) of reformulated Bologna sausages during chilled storage

\begin{tabular}{|c|c|c|c|c|c|c|c|}
\hline & & & & Days & & & \\
\hline & Samples & 0 & 15 & 30 & 45 & 60 & SEM \\
\hline & PF20/NS & $9.95^{\mathrm{aC}}$ & $10.47^{\mathrm{aBC}}$ & $10.83^{\mathrm{aAB}}$ & $10.69^{a b}$ & $11.46^{\mathrm{aA}}$ & 0.09 \\
\hline & PF20/RS & $9.37^{\mathrm{abcB}}$ & $9.21^{\mathrm{bB}}$ & $9.61^{\mathrm{bB}}$ & $10.35^{\mathrm{aA}}$ & $10.77^{\mathrm{abA}}$ & 0.10 \\
\hline & PF10/NS & $7.63^{\mathrm{dB}}$ & $7.86^{\mathrm{cAB}}$ & $7.58^{\mathrm{cB}}$ & $8.08^{\mathrm{bAB}}$ & $8.50^{\mathrm{cA}}$ & 0.09 \\
\hline & PF10/RS & $7.41^{\mathrm{dB}}$ & $7.56^{\mathrm{cB}}$ & $7.75^{\mathrm{cB}}$ & $8.51^{\mathrm{bA}}$ & $8.57^{\mathrm{CA}}$ & 0.09 \\
\hline dness $(\mathrm{N})$ & EG20/NS & $9.22^{\mathrm{bcc}}$ & $9.33^{\mathrm{bBC}}$ & $9.87^{\mathrm{bB}}$ & $10.76^{\mathrm{aA}}$ & $10.65^{\mathrm{bA}}$ & 0.09 \\
\hline & EG20/RS & $8.90^{\mathrm{cC}}$ & $9.11^{\mathrm{bC}}$ & $9.85^{\mathrm{bB}}$ & $10.60^{\mathrm{aA}}$ & $10.09^{\mathrm{bAB}}$ & 0.09 \\
\hline & PF10-EG10/NS & $9.64^{\mathrm{abC}}$ & $9.37^{\mathrm{bC}}$ & $9.60^{\mathrm{bC}}$ & $10.53^{\mathrm{aA}}$ & $10.02^{\mathrm{bAB}}$ & 0.10 \\
\hline & PF10-EG10/RS & $9.38^{a b c D}$ & $9.55^{\mathrm{bCD}}$ & $10.18^{\mathrm{bBC}}$ & $11.22^{\mathrm{aA}}$ & $10.65^{\mathrm{bAB}}$ & 0.11 \\
\hline & SEM & 0.08 & 0.09 & 0.10 & 0.11 & 0.10 & \\
\hline & PF20/NS & $0.90^{\mathrm{bNS}}$ & $0.89^{\mathrm{dNS}}{ }^{*}$ & $0.90^{\mathrm{bcNS}}{ }^{*}$ & $0.91^{\mathrm{abNS}}{ }^{*}$ & $0.89^{\mathrm{CNS}^{*}}$ & $<0.001$ \\
\hline & PF20/RS & $0.89^{\mathrm{bNS}}{ }^{*}$ & $0.89^{\mathrm{cdNS}^{*}}$ & $0.89^{\mathrm{cNS}^{*}}$ & $0.90^{\mathrm{bNS}}{ }^{*}$ & $0.91^{\mathrm{bcNS}}{ }^{*}$ & $<0.001$ \\
\hline & PF10/NS & $0.91^{\mathrm{abNS}}{ }^{*}$ & $0.91^{\mathrm{bcNS}^{*}}$ & $0.91^{a b c N S^{*}}$ & $0.92^{\mathrm{aNS} *}$ & $0.92^{\mathrm{abNS}}{ }^{\star}$ & $<0.001$ \\
\hline & PF10/RS & $0.90^{\mathrm{abB}}$ & $0.91^{\mathrm{bAB}}$ & $0.91^{\mathrm{abAB}}$ & $0.90^{\mathrm{abB}}$ & $0.92^{\mathrm{abA}}$ & $<0.001$ \\
\hline & EG20/NS & $0.91^{\mathrm{abC}}$ & $0.93^{\mathrm{aAB}}$ & $0.93^{\mathrm{aAB}}$ & $0.92^{\mathrm{abBC}}$ & $0.94^{\mathrm{aA}}$ & $<0.001$ \\
\hline & EG20/RS & $0.92^{\mathrm{aAB}}$ & $0.92^{\mathrm{abAB}}$ & $0.92^{\mathrm{aB}}$ & $0.92^{\mathrm{abAB}}$ & $0.93^{\mathrm{aA}}$ & $<0.001$ \\
\hline & PF10-EG10/NS & $0.90^{\mathrm{abNS}}$ & $0.91^{\mathrm{bcNS}}{ }^{*}$ & $0.91^{\mathrm{aNS}^{*}}$ & $0.92^{\mathrm{abNS} *}$ & $0.92^{\mathrm{abNS}}$ & $<0.001$ \\
\hline & PF10-EG10/RS & $0.90^{\mathrm{abNS}}{ }^{*}$ & $0.91^{\mathrm{bNS}}{ }^{*}$ & $0.91^{\mathrm{abNS}}{ }^{*}$ & $0.91^{\mathrm{abNS} \mathrm{s}^{\mathrm{x}}}$ & $0.91^{\text {bcNS"x }}$ & $<0.001$ \\
\hline & SEM & 0.00 & 0.00 & 0.00 & 0.00 & 0.00 & \\
\hline & PF20/NS & $0.79^{\text {cdeB }}$ & $0.79^{\mathrm{CB}}$ & $0.79^{\mathrm{dB}}$ & $0.81^{\mathrm{bA}}$ & $0.79^{\mathrm{dB}}$ & $<0.001$ \\
\hline & PF20/RS & $0.78^{\mathrm{eB}}$ & $0.80^{\mathrm{bcA}}$ & $0.80^{\mathrm{cd} A}$ & $0.80^{\mathrm{bcA}}$ & $0.80^{\mathrm{cdA}}$ & $<0.001$ \\
\hline & PF10/NS & $0.79^{\mathrm{bcc}}$ & $0.80^{\mathrm{abBC}}$ & $0.81^{\mathrm{ab} A B}$ & $0.82^{\mathrm{aA}}$ & $0.81^{\mathrm{abAB}}$ & $<0.001$ \\
\hline & PF10/RS & $0.78^{\mathrm{deB}}$ & $0.80^{\mathrm{bcA}}$ & $0.80^{\mathrm{bcd} A}$ & $0.80^{\mathrm{cA}}$ & $0.80^{\mathrm{bcd} A}$ & $<0.001$ \\
\hline esiveness & EG20/NS & $0.80^{\mathrm{abB}}$ & $0.81^{\mathrm{aA}}$ & $0.81^{\mathrm{aA}}$ & $0.81^{\mathrm{bcAB}}$ & $0.81^{\mathrm{abA}}$ & $<0.001$ \\
\hline & EG20/RS & $0.80^{\mathrm{aB}}$ & $0.80^{\mathrm{abB}}$ & $0.80^{\mathrm{abcB}}$ & $0.80^{\mathrm{bcB}}$ & $0.82^{\mathrm{aA}}$ & $<0.001$ \\
\hline & PF10-EG10/NS & $0.79^{\mathrm{bcdC}}$ & $0.80^{\mathrm{bcBC}}$ & $0.80^{\mathrm{bc} A B}$ & $0.80^{\mathrm{bcBC}}$ & $0.81^{\mathrm{abcA}}$ & $<0.001$ \\
\hline & PF10-EG10/RS & $0.78^{\text {deB }}$ & $0.80^{\mathrm{abcA}}$ & $0.80^{\mathrm{cdA}}$ & $0.80^{\mathrm{CA}}$ & $0.80^{\mathrm{cdA}}$ & $<0.001$ \\
\hline & SEM & 0.00 & 0.00 & 0.00 & 0.00 & 0.00 & \\
\hline & PF20/NS & $7.07^{\mathrm{aC}}$ & $7.33^{\mathrm{aBC}}$ & $7.68^{\mathrm{aAB}}$ & $7.82^{\mathrm{abA}}$ & $8.12^{\mathrm{aA}}$ & 0.07 \\
\hline & PF20/RS & $6.55^{\mathrm{bB}}$ & $6.57^{\mathrm{bB}}$ & $6.87^{\mathrm{bB}}$ & $7.50^{\mathrm{bA}}$ & $7.81^{\mathrm{abA}}$ & 0.07 \\
\hline $\begin{array}{l}\text { WIness } \\
x \mathrm{~mm} \text { ) }\end{array}$ & PF10/NS & $5.50^{\mathrm{cBC}}$ & $5.73^{\mathrm{CABC}}$ & $5.28^{\mathrm{cC}}$ & $6.11^{\mathrm{CAB}}$ & $6.35^{\mathrm{cA}}$ & 0.08 \\
\hline & PF10/RS & $5.22^{\mathrm{cC}}$ & $5.47^{\mathrm{cC}}$ & $5.66^{\mathrm{cBC}}$ & $6.12^{\mathrm{CAB}}$ & $6.35^{\mathrm{CA}}$ & 0.07 \\
\hline & EG20/NS & $6.69^{\mathrm{abc}}$ & $7.05^{\mathrm{abBC}}$ & $7.41^{\mathrm{abB}}$ & $7.95^{\mathrm{abA}}$ & $8.13^{\mathrm{aA}}$ & 0.08 \\
\hline
\end{tabular}




\begin{tabular}{ccccccc} 
EG20/RS & $6.58^{\mathrm{bC}}$ & $6.76^{\mathrm{bC}}$ & $7.26^{\mathrm{abB}}$ & $7.84^{\mathrm{abA}}$ & $7.69^{\mathrm{abAB}}$ & 0.07 \\
PF10-EG10/NS & $6.90^{\mathrm{abB}}$ & $6.77^{\mathrm{bB}}$ & $6.77^{\mathrm{bB}}$ & $7.69^{\mathrm{abA}}$ & $7.46^{\mathrm{bAB}}$ & 0.10 \\
PF10-EG10/RS & $6.64^{\mathrm{abD}}$ & $6.96^{\mathrm{abCD}}$ & $7.41^{\mathrm{abBC}}$ & $8.15^{\mathrm{aA}}$ & $7.78^{\mathrm{abAB}}$ & 0.08 \\
\hline SEM & 0.06 & 0.06 & 0.09 & 0.08 & 0.07 & \\
\hline
\end{tabular}

Equal lower case letters in the same column are not statistically different $(p>0.05)$. Equal capital letters in the same row for the same parameter are not statistically different $(p>0.05)$.Note: $S^{*}$, not significant. PF- pork back fat; NS- normal salt; RS- reduced salt; EG- emulsion gel.

Table 6. Microorganisms count (log cfu/g) of reformulated Bologna sausage during chilled storage

\begin{tabular}{|c|c|c|c|c|c|c|}
\hline \multirow[b]{2}{*}{ Microorganism } & \multirow[b]{2}{*}{ Samples } & \multicolumn{5}{|c|}{ Days } \\
\hline & & 0 & 15 & 30 & 45 & 60 \\
\hline \multirow{5}{*}{$\begin{array}{l}\text { Total viable count } \\
\text { (TVC) }\end{array}$} & PF20/NS & $3.1 \pm 0.1^{a b N S^{*}}$ & $2.9 \pm 0.1^{\mathrm{bNS}}$ & $2.8 \pm 0.0^{\mathrm{bcNS}}$ & $2.9 \pm 0.0^{\mathrm{aNS}^{*}}$ & $3.0 \pm 0.0^{\mathrm{abNS}^{*}}$ \\
\hline & EG20/NS & $3.1 \pm 0.1^{\mathrm{abA}}$ & $2.9 \pm 0.0^{\mathrm{bAB}}$ & $2.7 \pm 0.1^{\mathrm{bc} A \mathrm{~B}}$ & $2.6 \pm 0.1^{\mathrm{bB}}$ & $2.9 \pm 0.3^{\mathrm{abA}}$ \\
\hline & EG20/RS & $3.4 \pm 0.4^{\mathrm{Aab}}$ & $3.5 \pm 0.2^{\mathrm{aA}}$ & $2.9 \pm 0.0^{\mathrm{Bbc}}$ & $2.8 \pm 0.0^{\mathrm{abc}}$ & $3.3 \pm 0.4^{\mathrm{aABC}}$ \\
\hline & PF10-EG10/NS & $2.9 \pm 0.1^{\mathrm{bB}}$ & $2.9 \pm 0.1^{\mathrm{bBC}}$ & $3.6 \pm 0.1^{\mathrm{aA}}$ & $2.7 \pm 0.1^{\mathrm{abCD}}$ & $2.6 \pm 0.0^{\mathrm{bD}}$ \\
\hline & PF10-EG10/RS & $2.9 \pm 0.0^{\mathrm{bNS} S^{*}}$ & $2.7 \pm 0.3^{\mathrm{bNS}}$ & $2.6 \pm 0.1^{c N S^{*}}$ & $2.8 \pm 0.3^{\mathrm{abNS}}{ }^{*}$ & $2.6 \pm 0.2^{\mathrm{bNS} S^{*}}$ \\
\hline
\end{tabular}

Note: NS*, not significant; PF-pork back fat, EG- emulsion gel, NS-normal salt, RS-reduced salt. Equal capital letters in the same row for the same parameter are not statistically different $(p>0.05)$. 